\title{
ROMANIAN JOURNAL
}

OF LIBRARY

AND INFORMATION SCIENCE

Vol. 16, Iss. 2

2020 


\section{CONTENTS}

\section{RESEARCH ARTICLES}

Lenuța Ursachi

Redefining the reference librarian in the university environment, 1

Mihai Constantinescu, Alina Danciu, Dana Haimana Volunteering in libraries: survey on Romanian public libraries, 12

\section{INTERVIEW}

Mihai Constantinescu

Interview with Delia Pantea, Bihor County Library (English version), 20

Interview with Delia Pantea, Bihor County Library (Romanian version), 24

Revista Română de Biblioteconomie şi Ştiinţa Informării/

Romanian Journal of Library and Information Science (RRBSI) 16(2), 2020

Quarterly journal edited by the Romanian Library Association http://www.rrbsi.ro ISSN 2559-5490, ISSN-L 1841-1940

Editor: Angela Repanovici, PhD, Professor, "Transilvania" University of Brasov

Assistant Editor:

Founding editor:
Mihai Constantinescu, University of Bucharest Mircea Regneală

RRBSI is indexed in EBSCO Library \& Information Science Source (starting with iss. 4, 2010), Central and Eastern European Online Library (CEEOL), Directory of Open Access Journals 


\title{
Redefining the reference librarian in the university environment
}

\author{
Lenuța Ursachi \\ Faculty of Letters, University of Bucharest \\ E-mail lenuta.stratu@drd.unibuc.ro.
}

The reference librarian and the services provided hold more than ever the attention of users at the "Dunărea de Jos" University Library of Galati (DJULG). The Internet, technology and struggle for survival left a significant mark on both librarians' skills and reference services in the new context of the information society. In order to align with new trends in librarianship and to respond effectively to the increasingly complex demands of users, the reference librarians had to move beyond the traditional and reinvent themselves. As a result, new skills have been acquired and new services emerged in the information landscape of the university library.

The paper examines the evolution of the reference services at DJULG over the last ten years, emphasizing the changes of the librarian profile in this area. The variety of information sources, the emergence of new information technologies, the movement on open access have been the main elements that contributed to the professional development of the reference librarian and the implementation of new models of services for users. The case of the university library in this study reveals different profiles of the reference librarian: researcher, educator in information literacy, bibliometrician, wikilibrarian, digital resources manager, reference manager etc. Not far from the truth, we can say that the reference librarian became a chameleon, from the perspective of information evolution and ensuring sustainable library services.

Keywords: reference librarian, digital services, academic libraries, library marketing, Romania

\section{Introduction}

The information has developed and diversified within an online environment which seems to be the number one friend of nowadays user. Researching a particular issue no longer depends on visiting the library, consulting catalogs, approaching the librarian or writing references collected down on the paper. The use of online library catalogs, mobile access to subscribed databases, open access to scientific information could be the reasons why the physical contact with the library was gradually replaced by the virtual one. Two questions arise here: can the online environment completely replace a library and is the opinion of a librarian still necessary? Undoubtedly, the library work environment has changed continuously, and the emergence of new information technologies is inevitable. Consequently, the reference work must be constantly rethought because the librarian's professional life will be engaged in a permanent competition.

The paper examines the evolution of the reference services at the "Dunărea de Jos" University Library of Galați (DJULG) in the last ten years, emphasizing the profile changes of the librarian in this area. The variety of information sources, the emergence of new information technologies, the movement on open access to information have been the main components that contributed to the professional development of the reference librarian and the implementation of new models of services for users. The case of the university library in this study presents to the readers a chameleon reference librarian: researcher, educator, bibliometrician, wikilibrarian, digital resources manager, reference manager etc. 


\section{Literature review}

Danner (1998) reviews the professional categories that handle information, including accountants, archivers, librarians, data administrators, information systems analysts, museographers, publishers, computer scientists. They are considered mediators because they use the right resources, which are delivered at the right time, in the most appropriate form so that they can be used at a cost that justifies the value of the communicated information. According to Danner (1998) what distinguishes the librarian from the other categories are the following characteristics:

the quality of information is a top priority;

the activities carried out are focused on content;

the user is guided to find out how the information is searched and where it is located.

In a similar way, in the chapter Radiography of a profession, the authors define the documentarian as the specialist in information processing, mediator and communicator (Buluță et al 2007 p. 105). The increase and diversification of the library fund indicated, at least in the first phase, some weaknesses of the librarian in terms of access to information content. She/he has to know how to select the most valuable information, from a wide typology of resources, to meet the expected needs of the user (Horvat 1996 p. 177). To do that, the librarian must know very well the collections of the library and be a good specialist in the field.

The emergence of new information technologies placed the librarian in a position to lose control over her/his qualification, in a sense that traditional skills were no longer enough in relation to the increasingly complex requirements of users. And if the work of a librarian depends on information technology, then her/his skills need to be improved in this direction. The literature pointed out two categories of librarians' skills: professional and personal. The professional skills refer to the understanding of information sources content or a particular topic of interest to the organization or user, how to use the right technology to obtain the information, how to manage, evaluate and deliver it or how to conduct an effective research. When speaking of the personal skills, we mean the commitment to provide excellent services, the interest to discover new challenges and opportunities related to the profession, effective communication skills, teamwork both as a leader and as a member, flexibility, etc. (Danner 1998).

The reference librarians (RL) are metaphorically called defined by Anghelescu (2008) as the showcase of the institution, being the first people users meet when they enter the library. The technologies provide new ways of searching and organizing information and certainly influence the reference work. Thus, a certain degree of emphasis should be put on learning and understanding them. In the past, the traditional library catalog, a flexible and incredibly versatile tool for researchers, was very important to the RL, perceived in those days as an information keeper or index creator. Once information abounded on the market, search and retrieval tools became very important, transforming RL into a technology expert. Goetsch (2008) and Coravu (2012 p. 62) draw the attention to the characteristics of RL and the necessary skills found on the recruitment pages of USA university libraries in the period 1995-2005:

- 1997 - the appearance of the Internet Explorer browser - the reference staff must have knowledge on the use of the Internet; the advertised positions referred to: the librarian responsible for electronic services, the librarian of electronic references, the librarian responsible for accessing databases or the reference librarian for network resources; the skills needed were related to online search and supporting users in this matter, use of printed or electronic resources, experience in computer applications (operating systems, software packages);

- 2000 - the appearance of the Google search engine - the advertised positions referred to: the librarian responsible for electronic/digital resources or services, the librarian of web services, the specialist interface librarian, the instructor librarian, etc.; the necessary competencies involved knowledge of electronic resources, applications and web development, personal training, use of statistics, web publishing, training sessions based on web technology; at that time, RLs used various web applications to provide virtual assistance to users such as e-mail, chat or instant messaging; 
- 2005 - digital becomes the watchword, the mediated positions listed the digital applications and system librarian, digital initiatives librarian or the librarian responsible for electronic training of users; competencies were associated with technical services rather than reference services.

As Coravu (2012 p. 63) argued we won't meet such library positions in Romania. Therefore we can appreciate that the classification of library profession in Romania is dry when we refer to librarian, bibliographer, documentarian, researcher, system analyst etc. The reference librarian is not found in Romanian nomenclature, being more a term adopted from USA, associated with the type of services provided. The emergence of new information technologies and the abundance of information on various media, make their mark on the activity of RL. Anghelescu (2008) stated that RLs moved away [from] their work with the book and reformed the reference area by giving up traditional activities and penetrating the digital sphere.

\section{RL profile at DJULG during 2010-2020}

\subsection{The evolution of RL responsibilities and bibliographic activity}

The Reference and Bibliographic Research Department of DJULG has gone through some changes in terms of its name: the Bibliographic Information Department (1996), the Bibliographic Information and Documentation Department (2003) and the Reference and Bibliographic Research Department (2008-onwards). Since 1997, the team of this department consisted only in one librarian with higher education who was processing the complex inquiries. Article 16 of the Regulations on organizing and functioning of the DJULG (ROF) approved in 2003 mentioned the bibliographic and information tools developed at that time by the Bibliographic Information and Documentation Department (Biblioteca Universității “Dunărea de Jos” din Galați 2003):

- Bibliographic bulletin (list of new books entered in the library collections) - edited four times a year;

- $\quad$ Repertory of periodicals entered in the library collections - with annual frequency;

- $\quad$ Repertory of doctoral theses supervised by professors affiliated at DJUG - with annual frequency;

- $\quad$ Library guide - occasionally published.

The ROF revised in 2008 included five articles to the activity carried out by RL within the Reference and Bibliographic Research Department. The activities performed were also mentioned in the job description (Biblioteca Universității "Dunărea de Jos" din Galați 2008):

- $\quad$ orienting and informing the user about collections, services, tools and management of the library;

- $\quad$ bibliographic information and users' interests regarding the purchase of publications;

- $\quad$ editing of bibliographic materials (bulletins, repertories) in printed and electronic format;

- development of library marketing tools (guides, brochures, flyers)

- $\quad$ providing specific references in person or electronically (by e-mail);

- $\quad$ conducting the reference interview and solving the bibliographic research inquiries;

- $\quad$ updating the library web page in terms of library collections and events;

- $\quad$ creating new information tools for users;

- $\quad$ providing statistical data related to the reference area;

- $\quad$ reporting inaccuracies found in the integrated library software.

The tools developed within the Reference Departament included two additional bibliographic materials: Bibliography of reference works entered in the library collections (occasionally) and Bibliography of Shakespeare publications entered in the library collections (occasionally). The year of 2019 brought to DJULG new regulations and two work procedures related to the reference position: Providing references and Developing information tools. The work procedures defined specific terminology and legislation, described the procedure itself (documents used, material resources, work stages), how the results are capitalized, what are the responsibilities of the RL and the types of documents used. Supplementary activities can be distinguished here:

- development of the digital institutional repository;

- $\quad$ administration of the library Facebook page;

- $\quad$ posting news on the library website;

- $\quad$ training sessions with library users. 
During the period of 2010-2020 there have been major changes in the reference activity mainly due to the impact of information technologies. At this moment, bibliographic bulletins are no longer printed, but they are available online, in the form of lists accessed via the online library catalog (OPAC). The bibliographies on specific topics are currently stored in digital format, being available through two important tools: digital repository and Microsoft Teams. Microsoft Teams has been adopted this year, once the COVID-19 pandemic had spread around the world. It becomes an essential tool for referencing, organizing training sessions or meetings and delivering electronic documents. Figure 1 shows how the requests made by library users are managed. They are grouped on different channels representing the university faculties. The RLs upload bibliographies and electronic documents in folders named by the topics investigated.

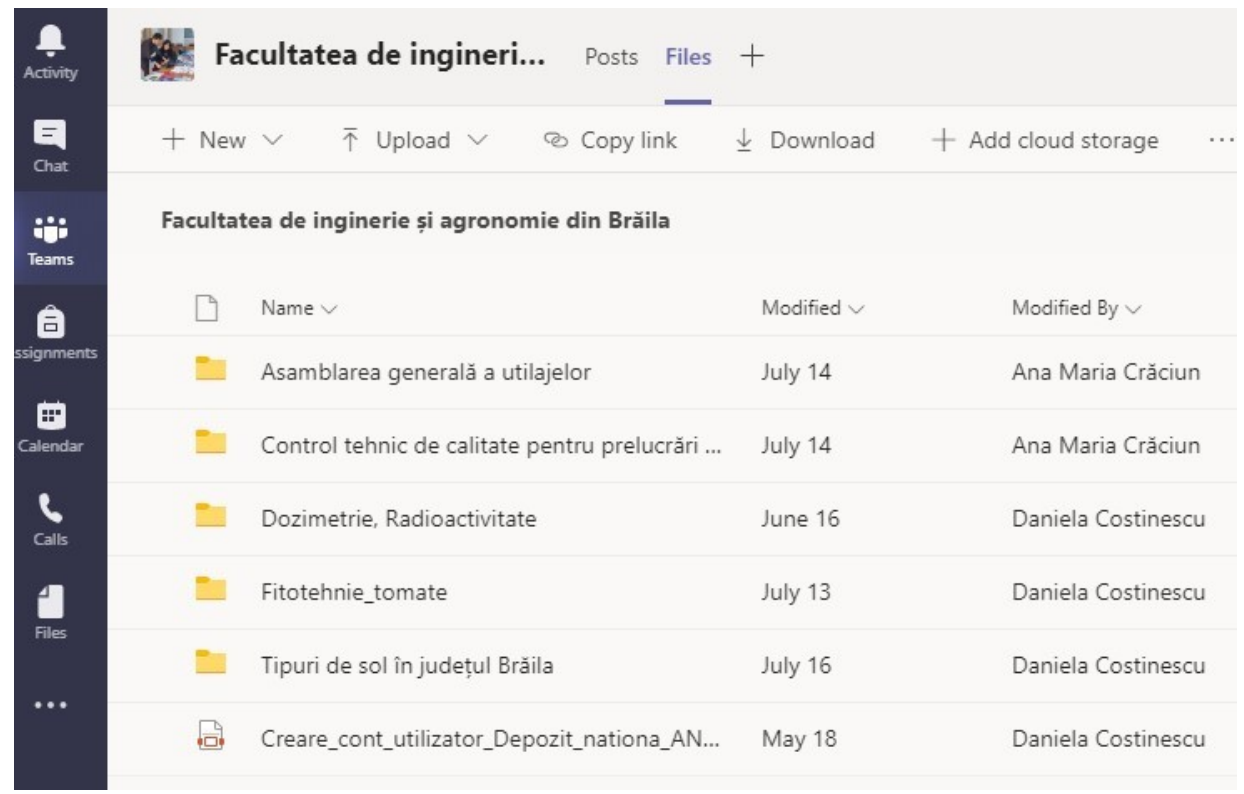

Figure 1. Bibliographies storage on Teams platform at DJULG

\subsection{The reference librarian as researcher}

The scientific research results have been published by the RLs from DJULG since 2010. Horvat Săluc (1996 p. 178) acknowledged that a librarian should conduct research and contribute to the enrichment of the library science. The topics discussed within the meetings of Reference Section and Information Literacy Section of the Romanian Librarians Association (ABR) have been always inspirational to the library community. The research activity at DJULG has been mainly focused on the following subjects, some of them being also disseminated at national and international events:

the world of the university librarian;

information literacy;

video tutorials;

citation models;

reference managers.

Besides published results, other topics have been studied during the analyzed period due to some internal projects, most of them being with reference to the information technology (integrated content management solutions, screenrecording software etc.).

\subsection{The reference librarian as educator in information literacy}

In 2012, the first set of information literacy tutorials in Romanian was published on a social media platform. Slideshare has been the chosen platform for instant publishing. The tutorials referred to the information sources used in research process, searching and locating information, citing information sources, creating the bibliography, etc. In the same year, a new form of collaboration with the faculties began to emerge. A set of seminars with a group of master students from the Faculty of Food Science and Engineering was organized. The focus was on information retrieval systems and ethical use of information. 
Subsequently, meetings with teachers, students and doctoral students followed and the area of debates was extended on other issues such as open access to information and remote navigation in databases, copyright issues, publishing alternatives and management of references. The opening academic year of 2016-2017 or 2017-2018 represented a special opportunity for RL to speak to groups of students from the Faculty of Legal, Social and Political Sciences. They were introduced in the process of searching and retrieving information through Koha library catalog, online databases and reference management. Similar seminars followed in 2019 and 2020 with master students from Faculty of Automatics, Computer Science, Electronics and Electrical Engineering. The meetings organized in 2020 took place on Microsoft Teams platform, due to COVID-19 pandemic.

\subsection{The reference librarian as reference manager}

Promoted since the end of 2013, the management of bibliographic references through software tools is still a topic accepted with some reservations by the academic community at DJUG. RL studied Mendeley, Zotero and EndNote and published a series of online guides in text and video format. Individual and group training sessions have been organized in the library as well as in faculty spaces since 2013. The paper The Reference librarian Face-to-Face with Reference Management (Ursachi 2018) described scenarios met during some of the reference interviews:

How can I organize different types of resources for my article?

How can I make a list of my papers indexed in Scopus or Web of Science?

How can I use a certain citation style for my article?

As team member in PERFORM project, RL had the position of short-term expert. Three meetings had been planned during the period April 2015-June 2015 aimed to develop the digital skills of the targeted audience consisted of doctoral and postdoctoral students. How to choose a citation manager (Mendeley, Zotero or EndNote online), online tools for digital researcher profile and bibliometric analysis in major databases were the main activities incorporated on the agenda of these meetings (Ursachi 2017).

Similar experiences took place in two different projects financed from innovation and development funds (FDI) in 2019 and 2020. Within these experiences, the RL was found in the position of educational expert. The refresher course on bibliographic references management organized by the Department of Continuing Education and Technology Transfer of DJUG in 2019 continued also in 2020. They facilitated the participation of academics and PhD students with the purpose to review their information and learn new skills needed for their profession. The meetings have been interactive and very constructive. The agenda covered information sources provided by the library, reference managers (Mendeley, Zotero, EndNote online) and Publish or Perish bibliometric tool. Unlike 2019, the course planned in 2020 took place in the online environment, through Microsoft Teams platform. In both cases, all participants created accounts on Mendeley and Zotero and joined the working groups created by the RL on each software website. For the final evaluation, the participants wrote a short text following the steps (Fig. 2):

- $\quad$ select one of the two softwares, Mendeley or Zotero;

- $\quad$ choose a citation style which fits to their field of interest or journal;

- $\quad$ create a folder within the working group of the software they choose to work with;

- $\quad$ search and save five references in their folders (the types of documents covered are: book, book chapter, journal article, conference proceeding and website);

- $\quad$ insert the citations in Word document and automatically create the bibliography. 


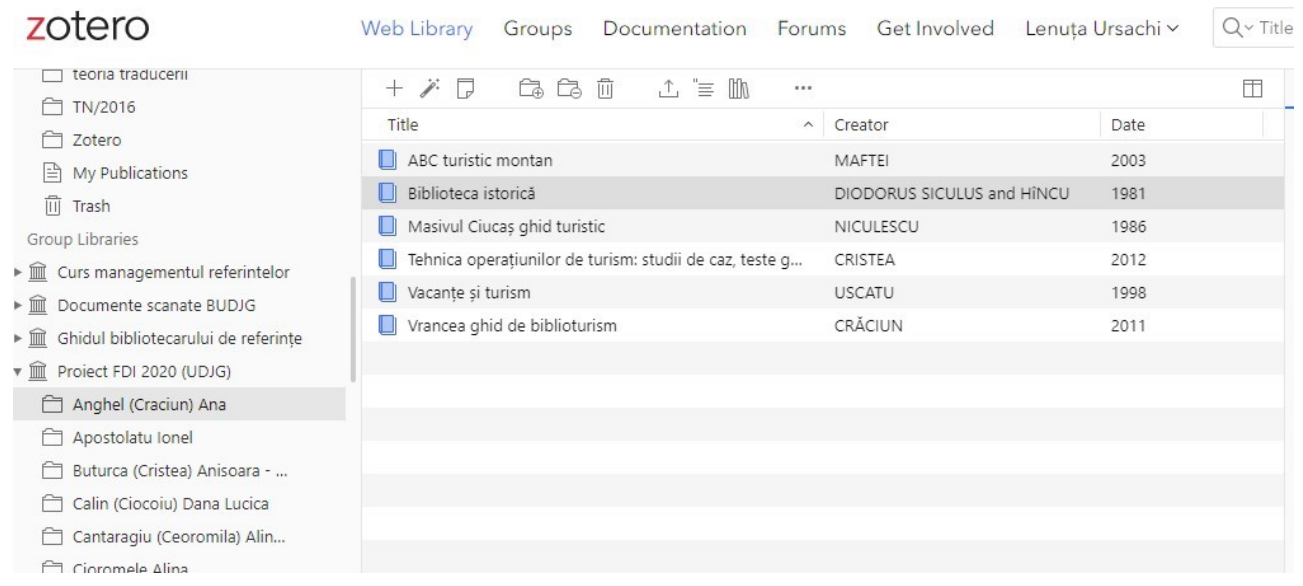

Figure 2. The working group of 2020 FDI project in Zotero

These courses were considered successful and here are some comments sent by the participants:

"I really enjoyed the course. Very well structured with up-to-date information. If you have more classes, I would love to participate. "

"New and valuable information".

"Repeated thanks for the enlightenment".

"Congratulations for the supporting and substantiating course."

"Thank you very much for the information provided, they are very helpful!"

"Thank you for your time and for everything we have learned from you!"

"Thank you for the information provided during the course and being available in the future!"

"Thanks for the information and knowledge you shared!".

\subsection{The reference librarian as digital services librarian}

The project regarding the new website of the library is based on the collaboration between the RL and IT member. The design solution and the main menus have been the RL's proposal. The IT member installed the software application and designed the main page. In addition, an administrator account has been created for the RL. The development of digital skills on editing in Joomla has resulted. Consequently, more than 200 web pages have beend designed, in a different manner than those included in the previous website version of 2012. Launched in August 2020, the new library website incorporated many elements focused on resources and scientific research: searching, evaluating and citing information, copyright and plagiarism, publishing of research results, digital services, etc. For the first time, three sets of webpages have been developed to promote reference managers through the website of DJULG (Fig. 3).

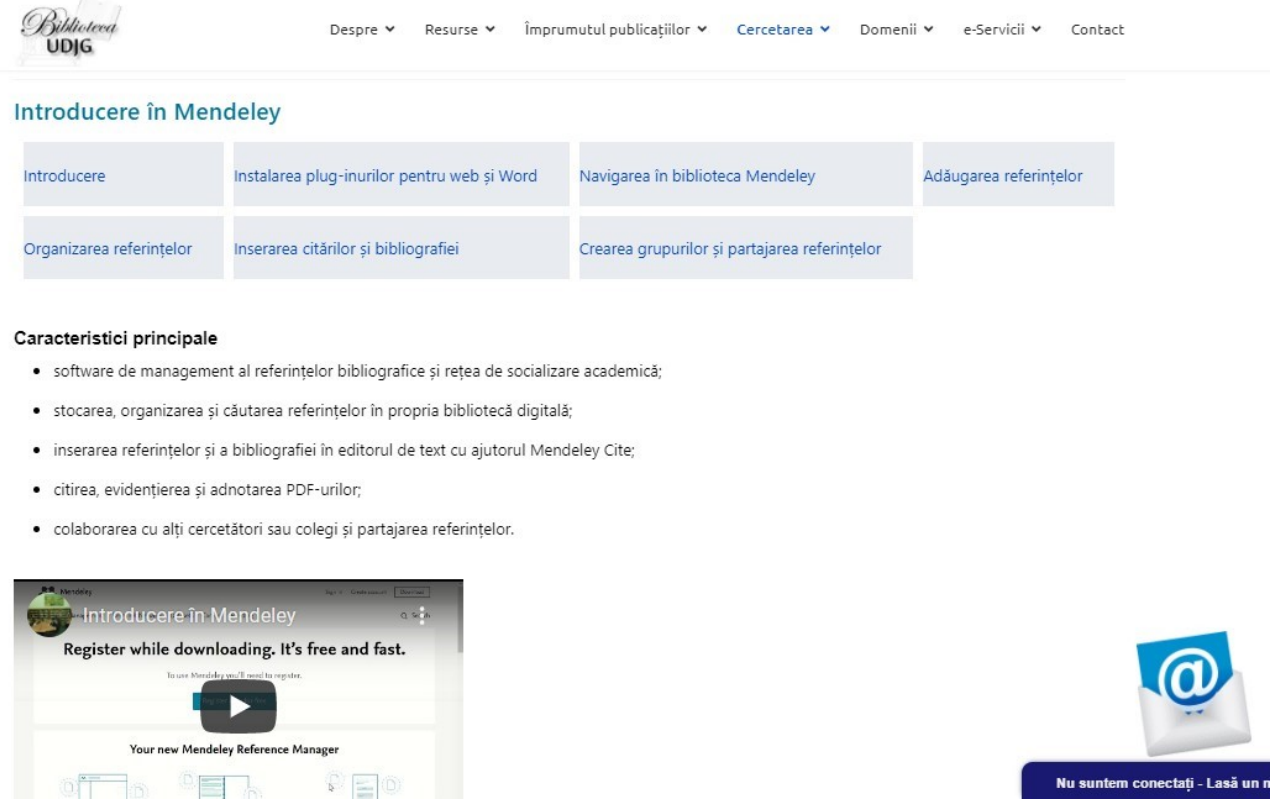

Figure 3. Mendeley presence on DJULG's website 
As mentioned before, the information has been edited in Joomla, both in "visual" mode and source code. Editing in "visual" mode is quite like in any text editor. The RL experienced editing in the source code in order to integrate the video guides published on YouTube (embed), use color CSS codes and a menu navigation. Each set of pages used the same pattern (with a small difference for EndNote online). It referred to the working steps with these softwares: account creation and software download, browsing the digital library, adding references, organizing references, inserting citations and bibliography and creating groups and sharing references.

The implementation of the Google Custom Search Engine (GCSE) service in 2017 was the consequence of the RL's participation at a webinar supported by the director of the National Science Library of Georgia. In order to put in practice the acquired knowledge, the search engine was set up by using the Google library account. GCSE has been built for multiple searches in Koha catalog, ARTHRA digital repository and library website. Subsequently, the source code provided was integrated within the homepage of library website.

The implementation of Koha in 2016 was an internal project of DJULG. The RL played a key role in the study of the MARC21 bibliographic format, the preparation of Koha user manual and the creation of video tutorials on Koha. The integration in 2018 of the library video guides in OPAC was another element of novelty for DJULG and the action was aiming to deliver remote services directly from the online catalog.

The development of the hosting platform for the scientific journals of DJUG and the implementation of the UGAL Index portal are other successful projects finished in 2019. The RL contributed to the creation of three journal websites by using Open Journal System and the library guide on how to navigate UGAL Index portal. The training session brought together the RL, academics and doctoral students from DJUG. Live demonstrations revealed to the audience the basic functions of the portal: simple, advanced and faceted search, browsing and results saving.

The digital reference services included social networks to keep a close contact with library users. LinkedIn, academia.edu, ResearchGate have been selected for the sharing of educational content. Moreover, the library's Facebook page was considered to be the perfect tool to promote events organized by the library and university, to share useful news from database providers or library catalog, etc. (Ursachi \& Scutelnicu 2012).

\subsection{The reference librarian as repository manager}

The implementation in 2011 of the ARTHRA institutional digital repository had a strong impact on the RL's activity. For the testing phase of the software, ARTHRA was chosen as the right tool for the electronic archiving of bibliographies. Later, library guides and statistics as well as librarians' articles and presentations have been included in ARTHRA. At this moment, the timplementation of DSpace-CRIS is ongoing. Besides research outputs, the new digital repository will manage researcher profiles (Fig. 4), organizations, projects and other entities (journals or events).

\subsection{The reference librarian as bibliometrician}

Cox, Gad \& Petersohn (2017) stated that bibliometrics is a subdiscipline of library and information science which aims to evaluate scientific research by using indicators and tools. The RLs deal with a proliferation of publication metrics which attempt to measure research at different levels: articles, journals, individuals, organizations, countries. The experience of using complex databases, knowledge of the indicators used in bibliometrics and altmetrics, the ability to share results of analysis in citation trends, alternative metrics, collaboration profiles are some of the main skills mentioned for the advertised jobs in higher education. Elizabeth Gadd (2017) underlined the importance of a good collaboration between library and research/planning office for the benefit of the institution. 


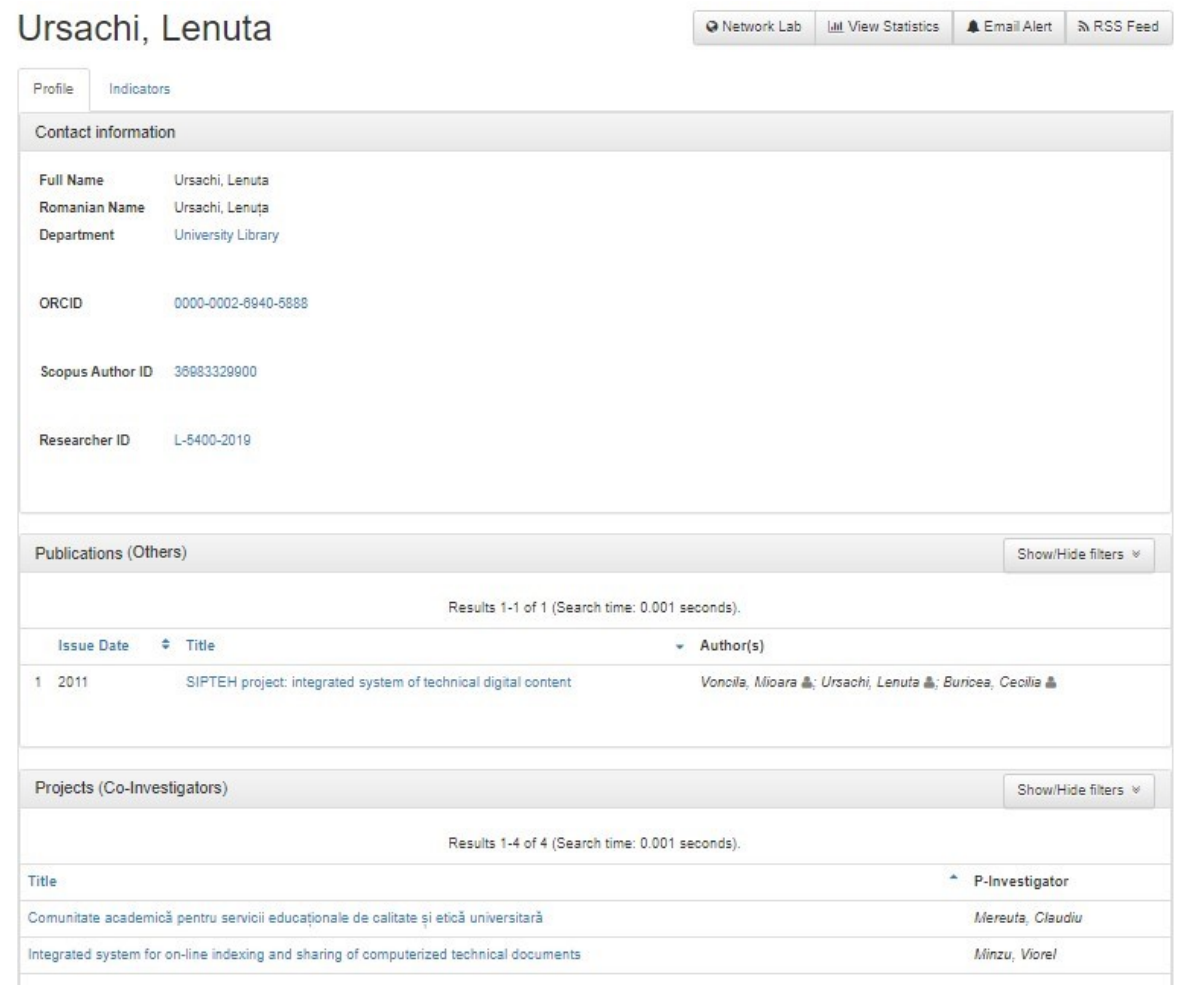

Figure 4. Researcher profile in CRIS-UGAL (ongoing project of DJUG)

An article published on the Altmetric blog reveals to readers some aspects connected to the research impact in Romania. The annual evaluation of the academics and the research trends are reflected in the number of publications and citations, number of journals included in red, yellow and grey zone (UEFISCDI classification) and h-index (Ursachi \& Huidiu 2016).

In 2015 , the RL had been approached by one of the vice-rectors to elaborate a series of working instructions in order to clarify the h-index search on three platforms: Google Scholar, Web of Science and Scopus. For a better understanding of the mechanism, three video guides were also developed by using CamStudio screenrecording software. Frequently, the RL supports academics on where to find their h-index and recommends them to sign up for services as Publons to eliminate the deficiencies detected in Web of Science author search. The library staff engaged in training sessions for the purpose of understanding bibliometrics.

In 2019, as team member in Expert project, the RL had to analyze the DJUG position in Shanghai top for the period 2015-2019. The report included definitions of the bibliometric indicators analyzed in Shanghai top, bibliometric data on Romanian universities extracted from 2015-2019 editions and a comparative analysis of the DJUG's position in relation to other Romanian universities. Conclusions drawn at the end of the document revealed the strengths and weaknesses of the institution in discussion (DJUG).

\subsection{The reference librarian as wikilibrarian}

The 1Lib1Ref campaign was an opportunity for RL to add references in Wikipedia. During the workshop "Wikimedia and librarians", organized by the National Library of Romania in 2019, librarians coming from all types of libraries were trained in wiki editing and adding images to Wikimedia. The event had a positive impact on RL from DJUG. A draft article created for DJULG included the most important elements that are specific to wiki pages: citing references, links to other wiki pages, inserting Wikimedia images, the brief information box, the Wikidata element (Fig. 5). 


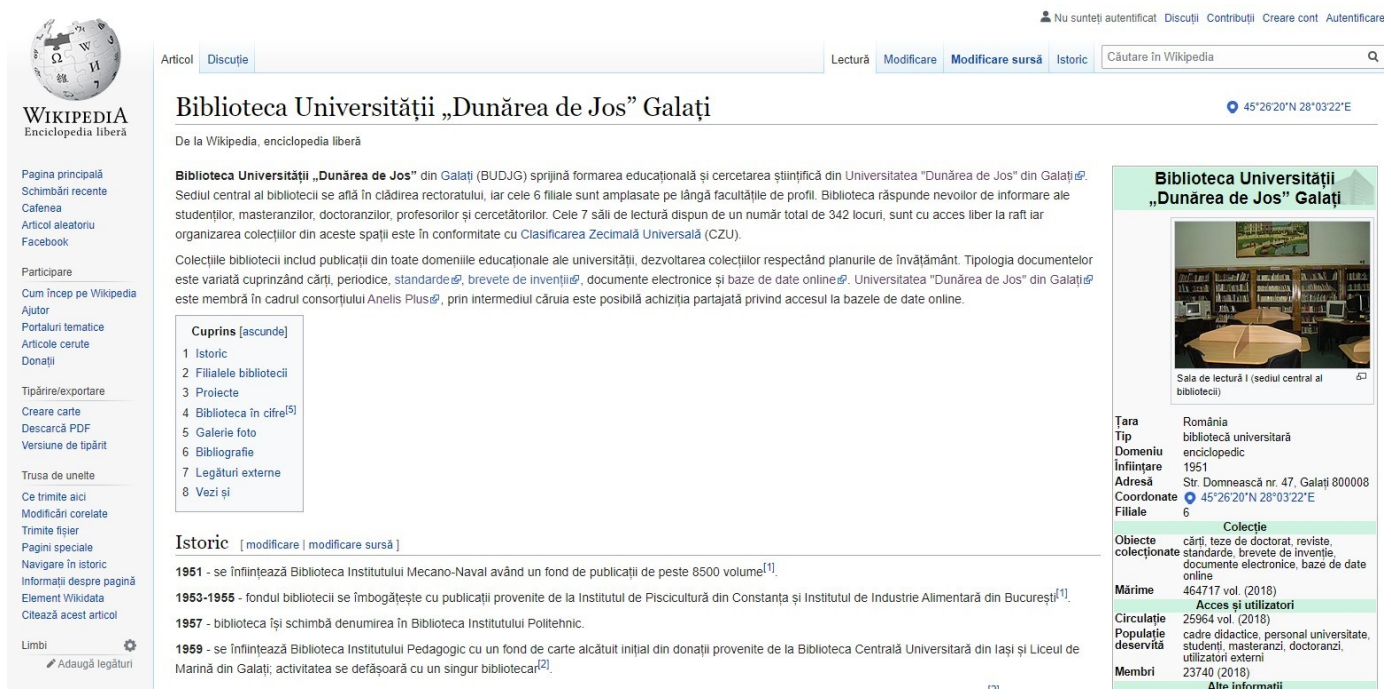

Figure 5. Wiki project of DJULG (Wikipedia 2019)

\subsection{The reference librarian and library marketing}

On a daily basis, RL is close to the users and looks for solutions to ensure the delivery of high quality products and services (Anghelescu \& Zănescu 2000 p. 37). In most of cases, the RL has been assigned to meet students in order to disseminate information about library collections and services. These meetings represent great opportunities to increase the library's visibility in the community. They are advertised on library website or Facebook page and participants received brochures or bookmarks before the event started. For the design of the marketing products, the RLs follow the AIDA model (Anghelescu \& Zănescu 2000 p. 47):

draw attention (A)

generate interest (I)

create a desire to use (D)

determine action (A).

RL exploited the digital tools provided by MS Office 2013 package or Canva for library marketing. The design combines image and text with taste, inventiveness and intelligence and the information is presented in such manner that arouses the reader's interest and desire to exploit (Ciorcan 1997 pp. 8-9). At DJULG, the RLs create and distribute marketing tools such as:

posters, to promote events organized by the library;

brochures, to offer information about collections, services and tools (Fig. 6);

bookmarks, to understand the systematic organization of library fund or the importance of reference managers;

library guides, to raise awareness of electronic resources.

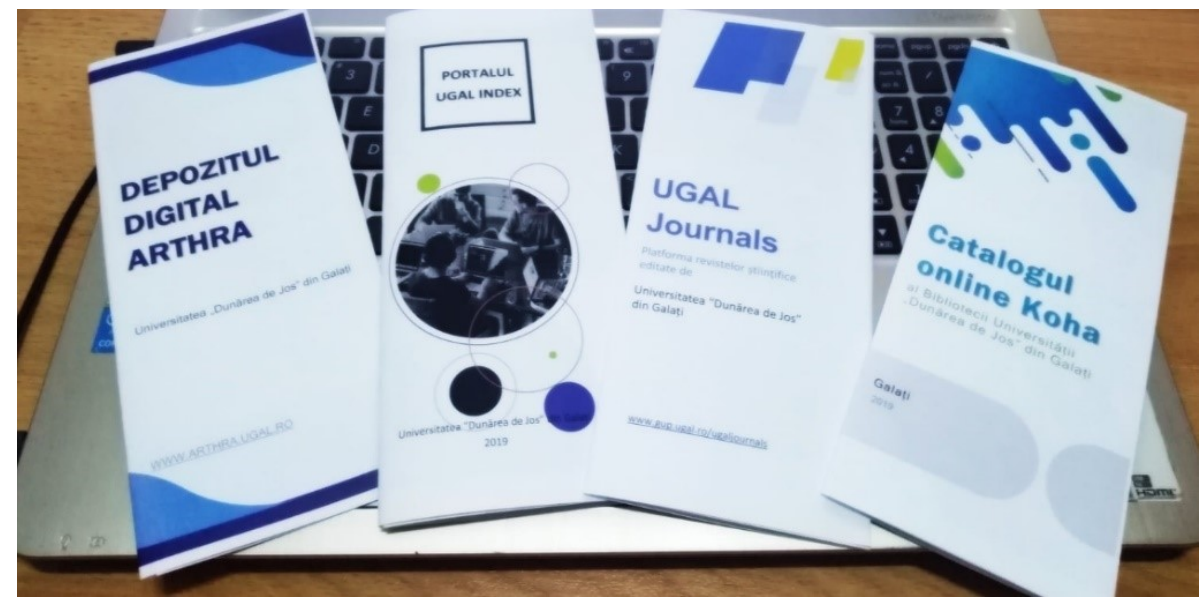

Figure 6. DJULG marketing products 


\section{Conclusions}

Information technologies have an extraordinary impact on both the user and librarian. They involve new strategies for finding and organizing information, changes in the information needs of users, with consequences on RLs and the services provided. Everyday work needs to be rethought and reinvented and some of the traditional activities should be eliminated. The RLs have to spend more time studying the trends in modern academic libraries as well as implementing new solutions aligned with the current requirements of the community served.

The RLs must not forget that the knowledge of library and information science is still essential, but, at the same time, it has to cope with the technological change. The library services are usercentered and the the RLs have to deliver proactive references. Their proficiency in digital and information literacy, constant development of personal and professional skills and discernment on what is good and efficient for the users, will integrate them more in the educational process (embedded librarians).

This study case looks over a few projects at DJULG and the redears perceive the RL as a person with high technical skills, with expertise in information retrieval and organization and software tools. The RL is able to develop and provide learning strategies to suit a particular situation which the user is facing during research process. The various cases described in this paper bring the RL in the position of quintessential mediator sitting between library and faculties (academics and students).

In conclusion, it is imperative for RLs to be continuously trained, flexible and open to new things. Consistent researches on what is relevant to the job might put some vibrant color in RL's life. Dedication to profession, willingness to help others and the continuous strive for excellence in services' delivery are the premises to elevate reference work to the rank of hobby.

\section{Acknowledgements}

I would like to express my cordial thanks to Vice-Rector, Prof. Dr. Eng. Elena Mereuță, Prof. Dr. Eng. Gabriela Elena Bahrim (former Vice-Rector), Prof. Dr. Mirela Voiculescu and Mioara Voncilă for the project experiences and to Vice-Rector, Assoc. Prof. Dr. Eng. Ciprian Vlad, Prof. Dr. Eng. Anca Ioana Nicolau (former Vice-Rector) and Prof. Dr. Florin Tudor for the opportunity to participate in seminars with students. 


\section{References}

Anghelescu, Hermina G.B. (2008) Serviciile de referință: Cheia succesului unei biblioteci, in Corghenci, L. (ed.) Dimensiuni manageriale în activitatea instituției info-bibliotecare: Concepte, experiențe, orientări, Chișinău: Universitatea Liberă Internațională din Moldova, pp. 56-60.

Anghelescu, H. and Zănescu, G. (eds) (2000) Necesitățile utilizatorilor şi familiarizarea cu resursele informaționale în pragul mileniului, Timișoara: Brumar.

Biblioteca Universității "Dunărea de Jos" din Galați (2003) Regulamentul de organizare și funcționare a Bibliotecii Universității "Dunărea de Jos" din Galați, Galați: Universitatea "Dunărea de Jos" din Galați.

Biblioteca Universității "Dunărea de Jos" din Galați (2008) Regulamentul de organizare și funcționare a Bibliotecii Universității "Dunărea de Jos" din Galați, Galați: Universitatea "Dunărea de Jos" din Galați.

Biblioteca Universității "Dunărea de Jos” din Galați (2019), Wikipedia [online], available: https:// ro.wikipedia.org/wiki/Biblioteca Universit $\% \mathrm{C} 4 \% 83 \% \mathrm{C} 8 \% 9 \mathrm{Bii} \% \mathrm{E} 2 \% 80 \% 9 \mathrm{EDun} \% \mathrm{C} 4 \%$

83rea de Jos\%E2\%80\%9D Gala\%C8\%9Bi [accessed 28 August 2019 18:55].

Buluță, G., Craia, S. and Petrescu, V. (2007) Biblioteca în societatea informației, București: DoMinoR.

Coravu, R. (2012) Intermediarul difuz: biblioteca universitară între cultura tiparului și cultura digitală, Constanța: Ex Ponto.

Cox, A., Gadd, E. and Petersohn, S. (2017) Competencies for bibliometrics, Journal of Academic Librarianship, 51(3) pp. 1-17, available: https://journals.sagepub.com/doi/ pdf/10.1177/0961000617728111 [accessed 16 November 2020].

Danner, R. A. (1998) Redefining a profession, Law Library Journal, 90(3) pp. 315-356.

Gadd, E. (2017) Bibliometrics a job for the library or the research office?, SCONUL Focus 69, pp. 35-37, available: https://www.sconul.ac.uk/publication/bibliometrics-a-job-for-the-library-or-theresearch-office [accessed 16 November 2020].

Goetsch, L. A. (2008) Reinventing our work: New and emerging roles for academic librarians, Journal of Library Administration, 48(2) pp. 157-172, available: https:// doi.org/10.1080/01930820802231351 [accessed 16 November 2020].

Horvat, S. (1996) Introducere în biblioteconomie, București: Grafoart.

Ursachi, L. (2017) Activități de cultura informației desfășurate în cadrul proiectului PERFORM, in Micle, M., Lovasz, A. and Bursașiu, S. coord. Biblioteca fără bariere : Conferințta Națională a Asociației Bibliotecarilor din România, Timișoara, 7-9 Septembrie 2016, Timișoara: Editura Universității de Vest ; București : Editura ABR, pp. 105-111.

Ursachi, L. (2018) The Reference Librarian Face-to-Face with Reference Management, Revista Română de Biblioteconomie și Știința Informării = Romanian Journal of Library and Information Science, 14(2) pp. 46-55, available: https://doi.org/10.26660/rrbsi.2018.14.2.46 [accessed 16 November 2020].

Ursachi, L. and Huidiu, C. (2016) Assessing the impact of research results in Romania, Altmetric Blog [online], available: https://www.altmetric.com/blog/assessing-the-impact-of-research-resultsin-romania [accessed 16 November 2020].

Ursachi, L. and Scutelnicu, E. (2012) New concepts and techniques implemented by Dunarea de Jos University Library of Galati, in Proceedings of the Third International Conference in Romania on Information Science and Information Literacy, Sibiu, April 22th - 24th 2012 [CD-ROM], Sibiu: Universitatea "Lucian Blaga" din Sibiu. 


\title{
Volunteering in libraries: survey on Romanian public libraries
}

\author{
Mihai Constantinescu \\ Faculty of Letters, University of Bucharest \\ E-mail constantin.mihai.escu@gmail.com \\ Alina Danciu \\ Faculty of Letters, University of Bucharest \\ E-mail danciu.alina123@gmail.com \\ Dana Haimana \\ Faculty of Letters, University of Bucharest \\ E-mail haimanadana@gmail.com
}

Libraries are a natural hotspot for volunteer work, they can act as both beneficiaries and organizers of volunteers and their work. Volunteer programs in the libraries cover an important range of possibilities, from basic library work (moving books, assisting users that need help) to specialized activities (language courses, computer courses, specialized activities with persons with disabilities) and everything in between.

This study aims to offer an overview of the situation regarding volunteer work in Romanian public libraries. It seeks to find out whether and how the county libraries and the two national libraries use volunteers. This study presents a brief analysis of the online presence of Romanian libraries.

Keywords: volunteering, libraries, study, Romania, Romanian libraries

\section{Introduction}

Libraries are a natural hotspot for volunteer work, they can act as both beneficiaries and organizers of volunteers and their work. Volunteer programs in the libraries cover an important range of possibilities, from basic library work (moving books, assisting users that need help) to specialized activities (language courses, computer courses, specialized activities with persons with disabilities) and everything in between. While volunteering can be and is done in all types of libraries, public libraries in particular seem to be the most prone to use (and need) help from volunteers. Moreover, public libraries are (theoretically) more open to a wider variety of public than any other type of library, thus having the most significant potential impact. Especially in the case of small towns, libraries can be the only place that offers the opportunity to volunteer.

Volunteers are an important resource for any library: they can help with activities that require abilities not possessed by librarians; they can help with all sorts of work around the library, from moving books to offering basic information retrieval help for patrons and much more. Especially in the cases of libraries that have limited resources or have experienced budget cuts (as is the case in more and more countries), volunteers can help with keeping alive services that would otherwise be condemned.

This study aims to offer an overview of the situation regarding volunteer work in Romanian public libraries. It seeks to find out whether and how the county libraries and the two national libraries use volunteers.

Revista Română de Biblioteconomie şi Ştiința Informării = Romanian Journal of Library and Information Science ISSN 2559-5490, ISSN-L 1841-1940 • Volume 16 Issue 22020 pp. 12-19 https://doi.org/10.26660/rrbsi.2020.16.2.12

This work is licensed under a Creative Commons Attribution-NonCommercial-NoDerivatives 4.0 International License 


\section{Methodology}

The study aimed to collect data from all the county libraries and the two national libraries (National Library of Romania and the Romanian Academy Library). We chose to analyze only these libraries because they are the largest and most important public libraries (or libraries that also fulfill a public library role - in the case of the national libraries). The data was collected in two steps, between February and March 2020. First, we collected data available on the libraries' websites and then we collected data directly from the libraries through a questionnaire created in Google Forms and sent via email (to the official email of the library - as stated on the website). From the websites we collected data regarding the volunteer programs (if any such information is available on the website, if information for prospective volunteers is available, the number of volunteer programs available at the library, the types of volunteer activities, and the depth of the volunteer programs/activities description - in number of words - see Annex 1 for full list of results). Through the questionnaire we collected data regarding the usage of volunteers in the libraries, the existence of a volunteer coordinator, a volunteer management strategy, and training for volunteers, the number of volunteers used in libraries (and if this number is considered to be sufficient), the types of activities done by them, and the reasons for using their work (see Annex 2 for full list of questions and results). From the total of 43 analysed libraries (the 41 county libraries and the two national libraries), we received responses for the questionnaire from 25 . Only 21 of the libraries had information regarding volunteering on their websites.

3. Study results

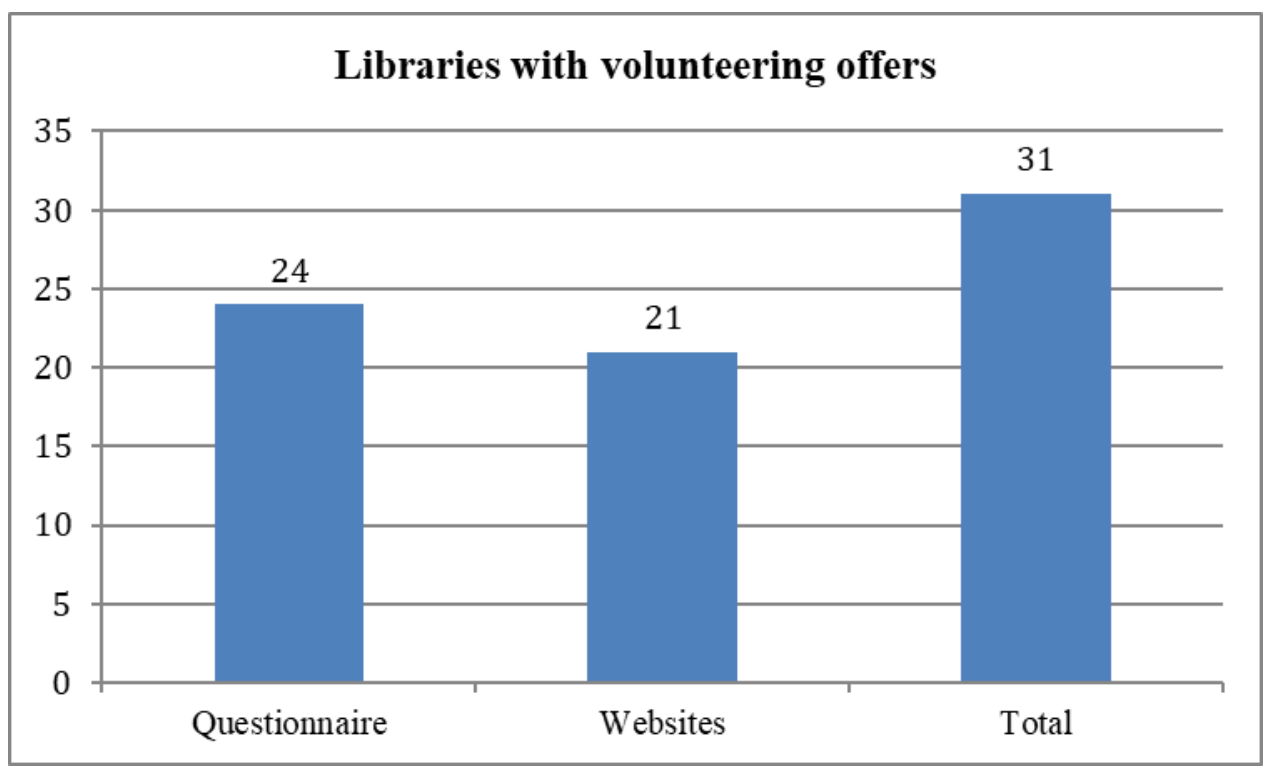

Fig. 1. Libraries that use volunteers

The analysis of the questionnaire answers shows that 24 libraries use volunteers, while only 21 libraries offer information about volunteering on their websites. In total, a number of 31 libraries offer volunteer opportunities (there is partial superposition between the ones that responded to the questionnaire and the ones that have information on their websites). This number means that more than two thirds of the total number of libraries use volunteers. We consider this to be a good starting point, especially taking into account that we did not receive any kind of response for the questionnaire from a significant part of the total number of libraries. 


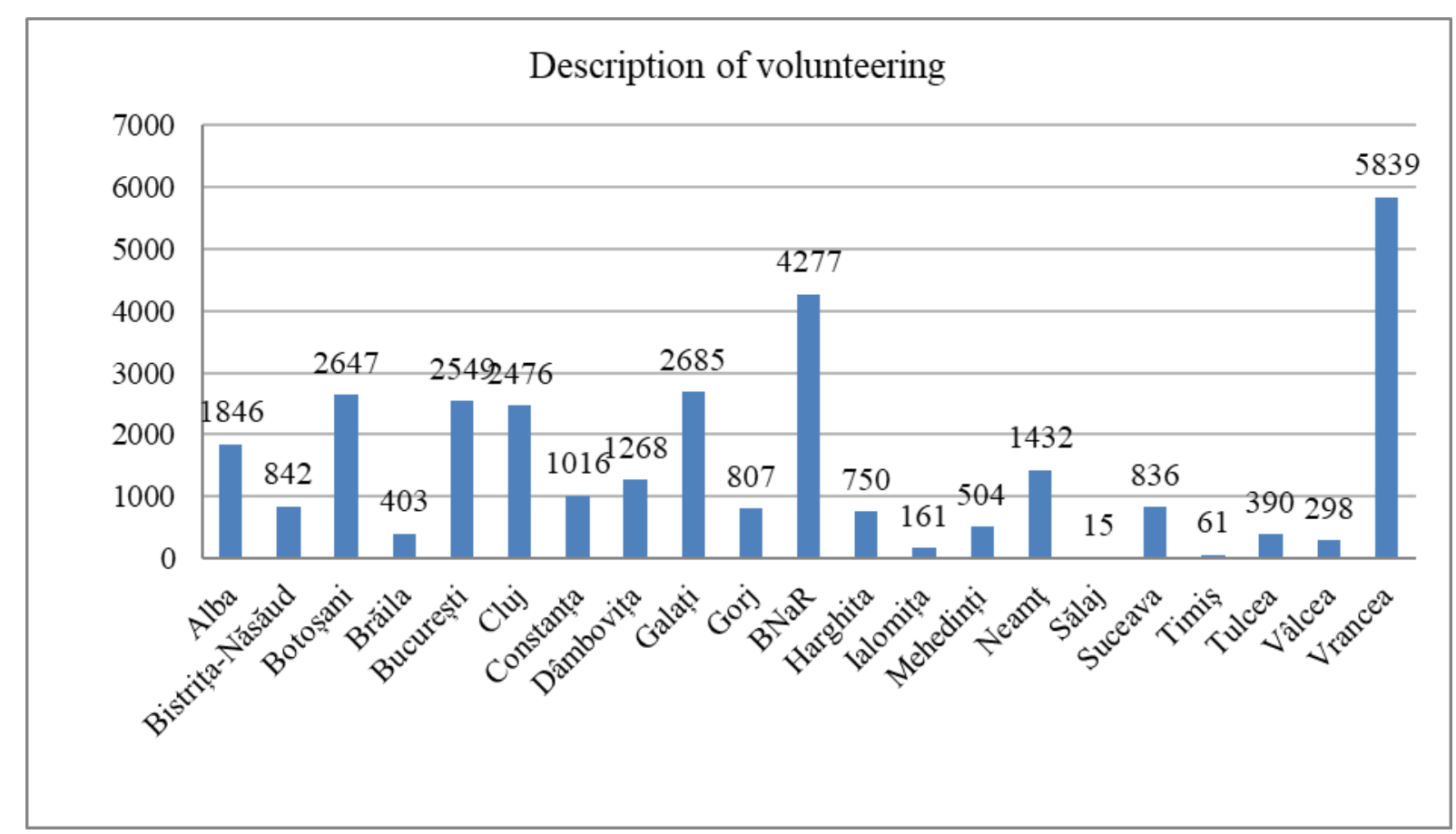

Fig. 2. Description of volunteering activities on the library websites in no. of words

The length of the description of the volunteer activities or any volunteer-related aspects (in number of words) can offer us a glimpse into the way in which libraries see volunteering. Some libraries write quite extensively about volunteering (the National Library and the County Library of Vrancea each have a more than 4000-word description). The average description is 1481 words long, while the median description is 842 words long. This difference clearly indicates that the average is significantly influenced by the libraries that have extensive descriptions and that an „average" library has a 800-word description. Two libraries have short descriptions (under 100 words), one of which has a barely 15 words description. We must keep in mind that this is only a quantitative analysis, therefore we cannot make judgements regarding the quality of the descriptions but we cannot wonder what can be said in 15 words and what does this say about the seriousness of the library and its attitude towards volunteering?

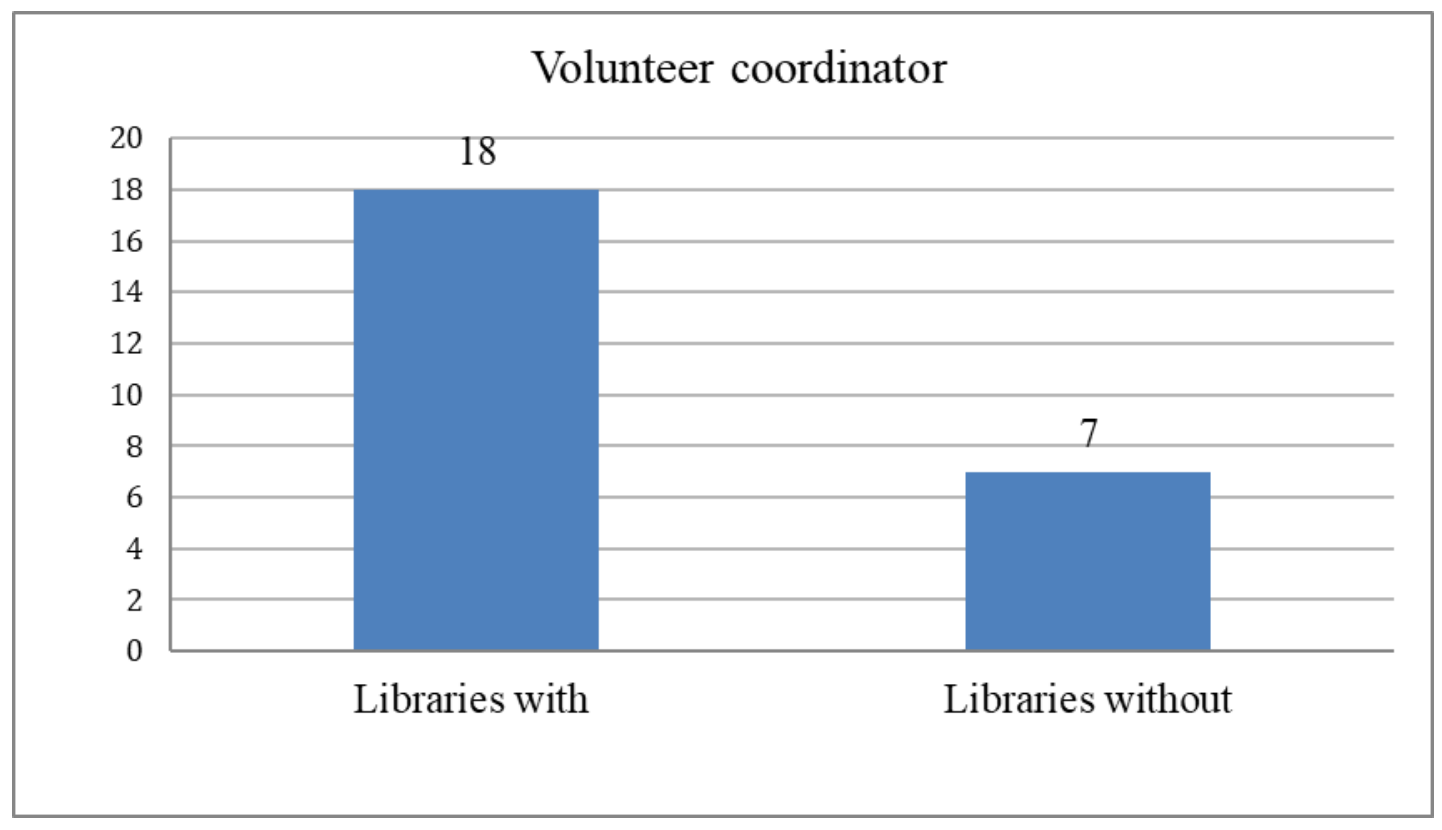

Fig. 3. Existence of a coordinator for volunteers 
Eighteen of the 25 libraries that responded to the questionnaire have a coordinator for volunteers. This is a positive aspect, showing that the vast majority of libraries treat aspects regarding volunteering with seriousness.

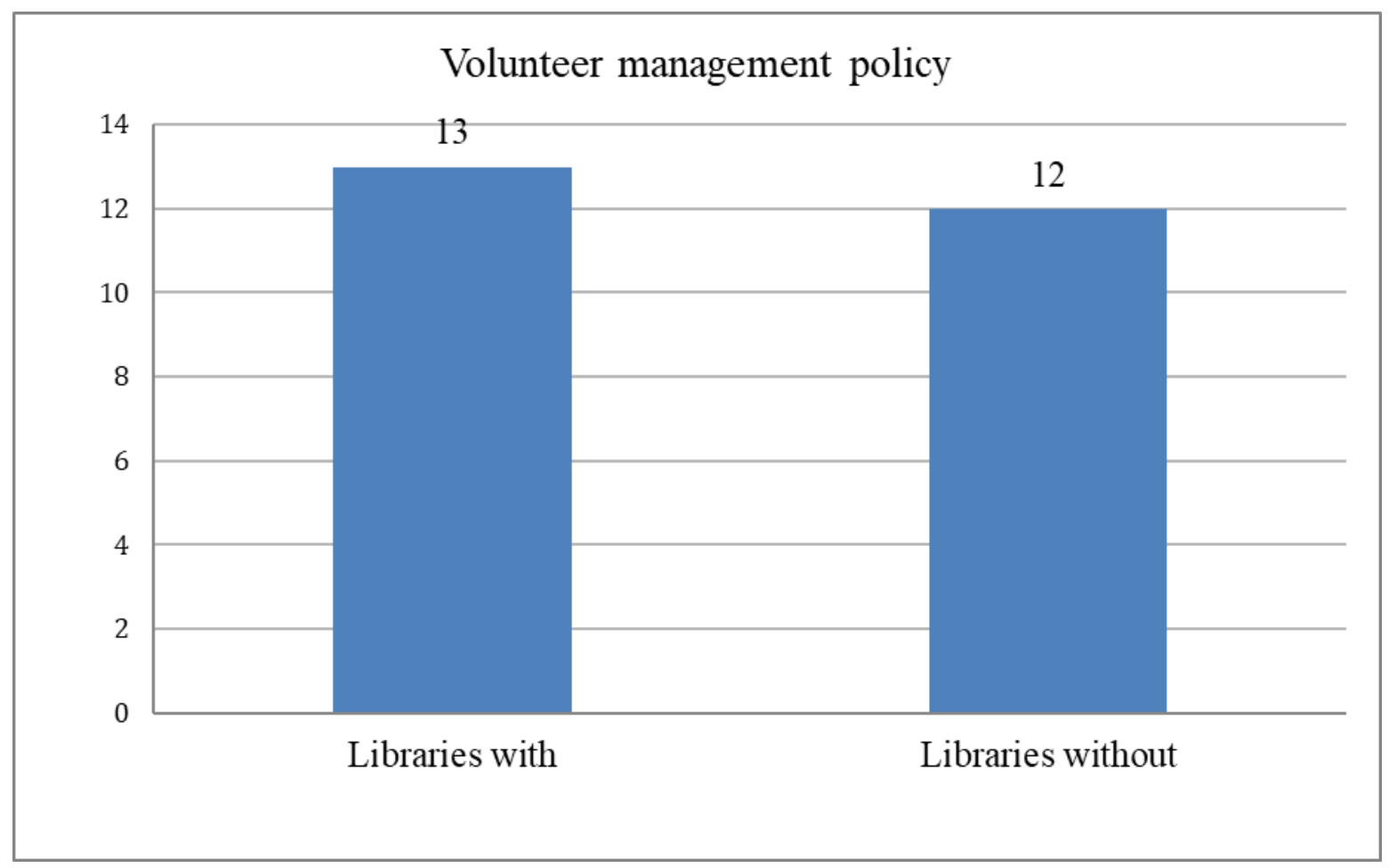

Fig. 4. Libraries that created a management policy for volunteers

Thirteen libraries from those that use volunteers have management policy for volunteers, the existence of which is a clear step forward in the professionalization of the work with volunteers. However, this shows that just over half of the libraries have a policy in place for volunteer work. Such a policy could help create a better environment for volunteering and ensure that the know-how and ability to work with volunteers is a library characteristic and not just a personal characteristic of one or more librarians (helping the library retain the ability to get and keep volunteers regardless of the existence a certain individual librarian).

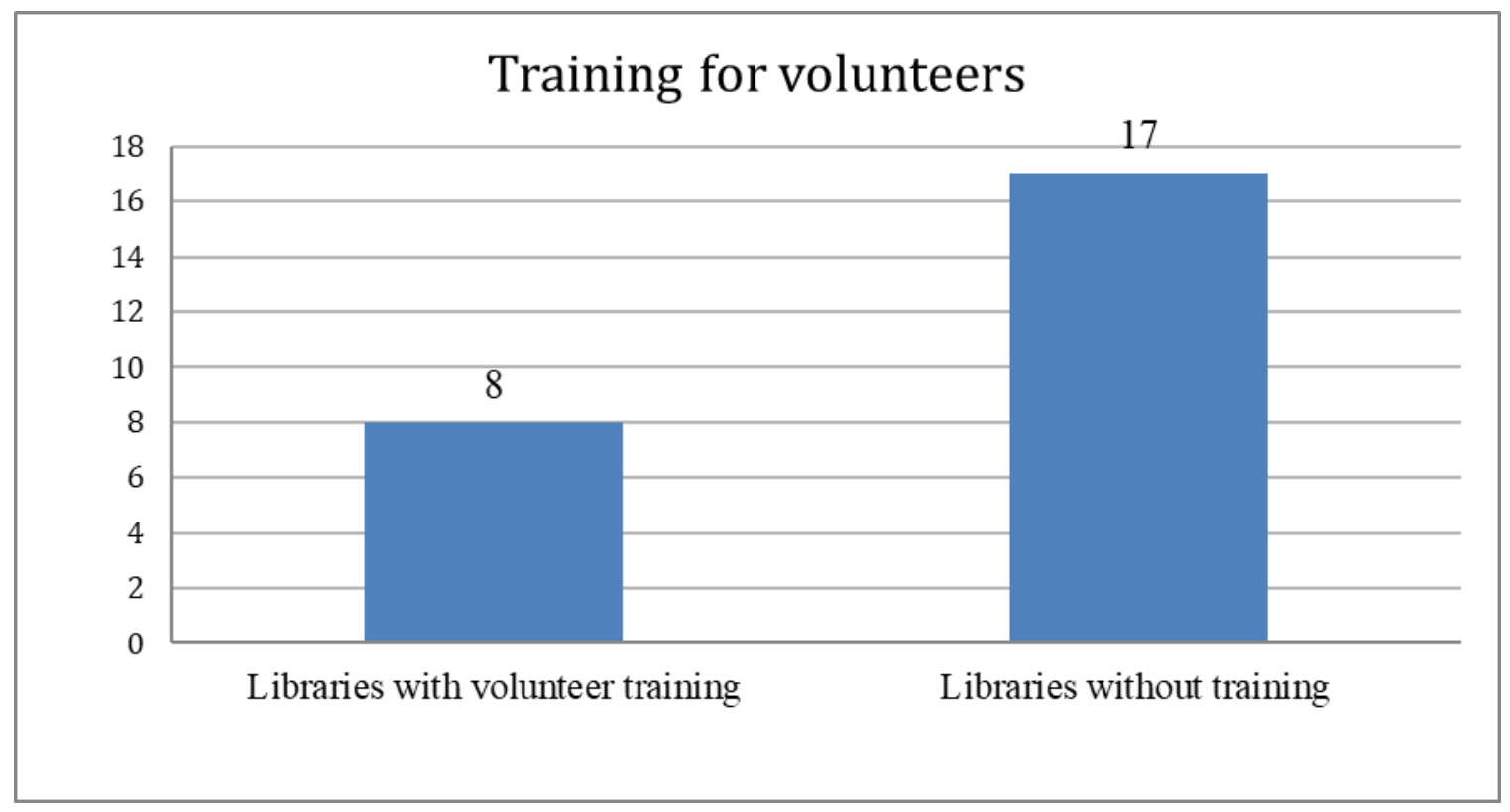

Fig. 5. Training for volunteers 
Only eight libraries offer training for volunteers. We can assume that libraries either use volunteers for different activities that don't require any training (physical activities, for example) or that libraries prefer to use volunteers that already have knowledge and experience in their fields.

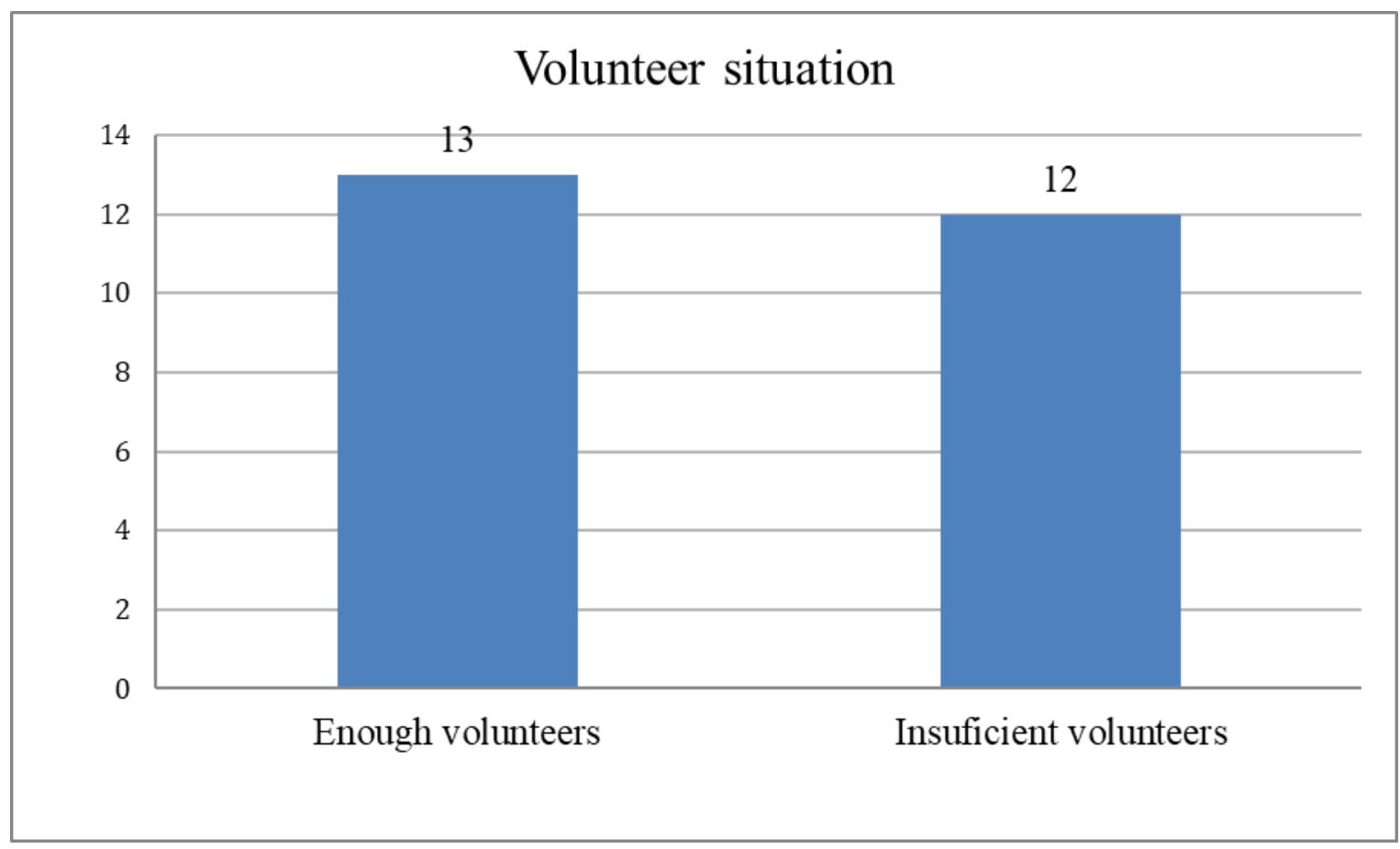

Fig.6 The situation of volunteers from a numerical point of view

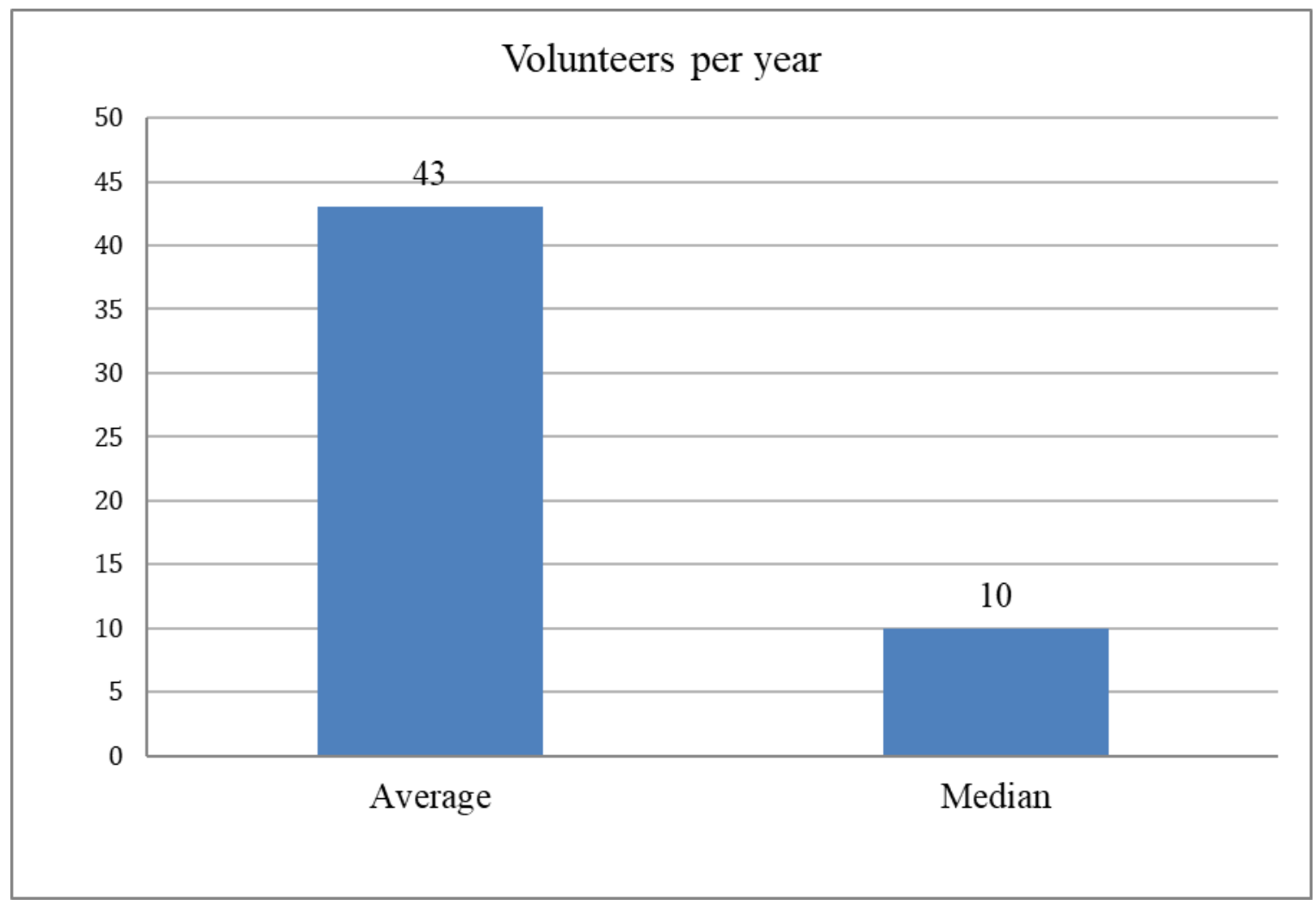

Fig. 7 Number of volunteers per year 
Thirteen of the twenty-five libraries consider the number of volunteers as sufficient. This situation shows us that more volunteers are needed and, maybe, that libraries need to improve their appeal to volunteers.

In average, a library has 43 volunteers. However, this number is highly distorted by libraries with a large number of volunteers: the median number of volunteers is barely 10 . This means that half of the total number of libraries has 10 or less volunteers per year, which is a low number, especially when we take into account the fact that the analysed libraries are big county libraries and the two national libraries.

There are libraries that have 200 volunteers each year, but also libraries with only two volunteers per year. This discrepancy is significant and should indicate that more can be done in certain cases to attract volunteers.

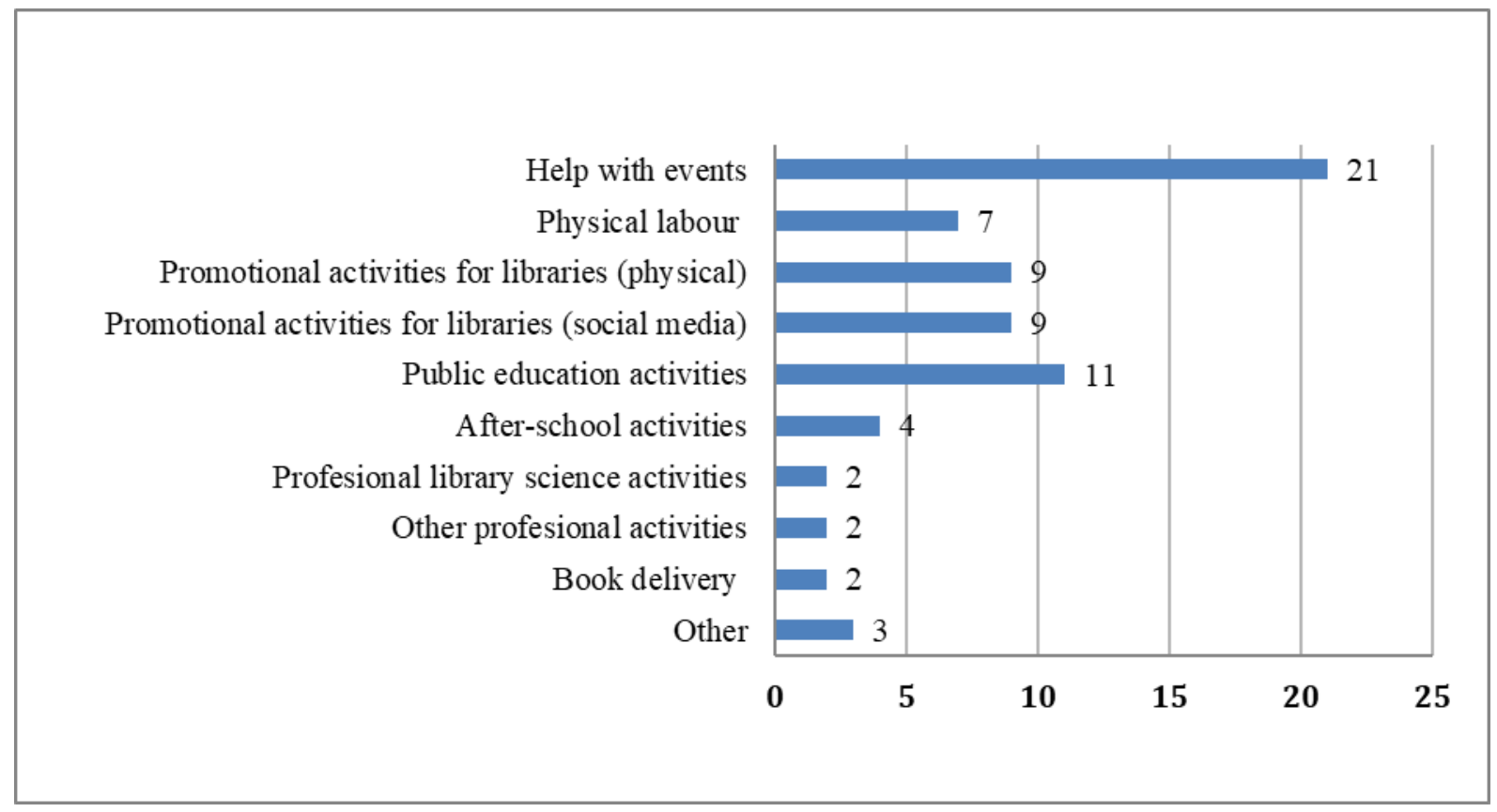

Fig. 8 Volunteers - activities

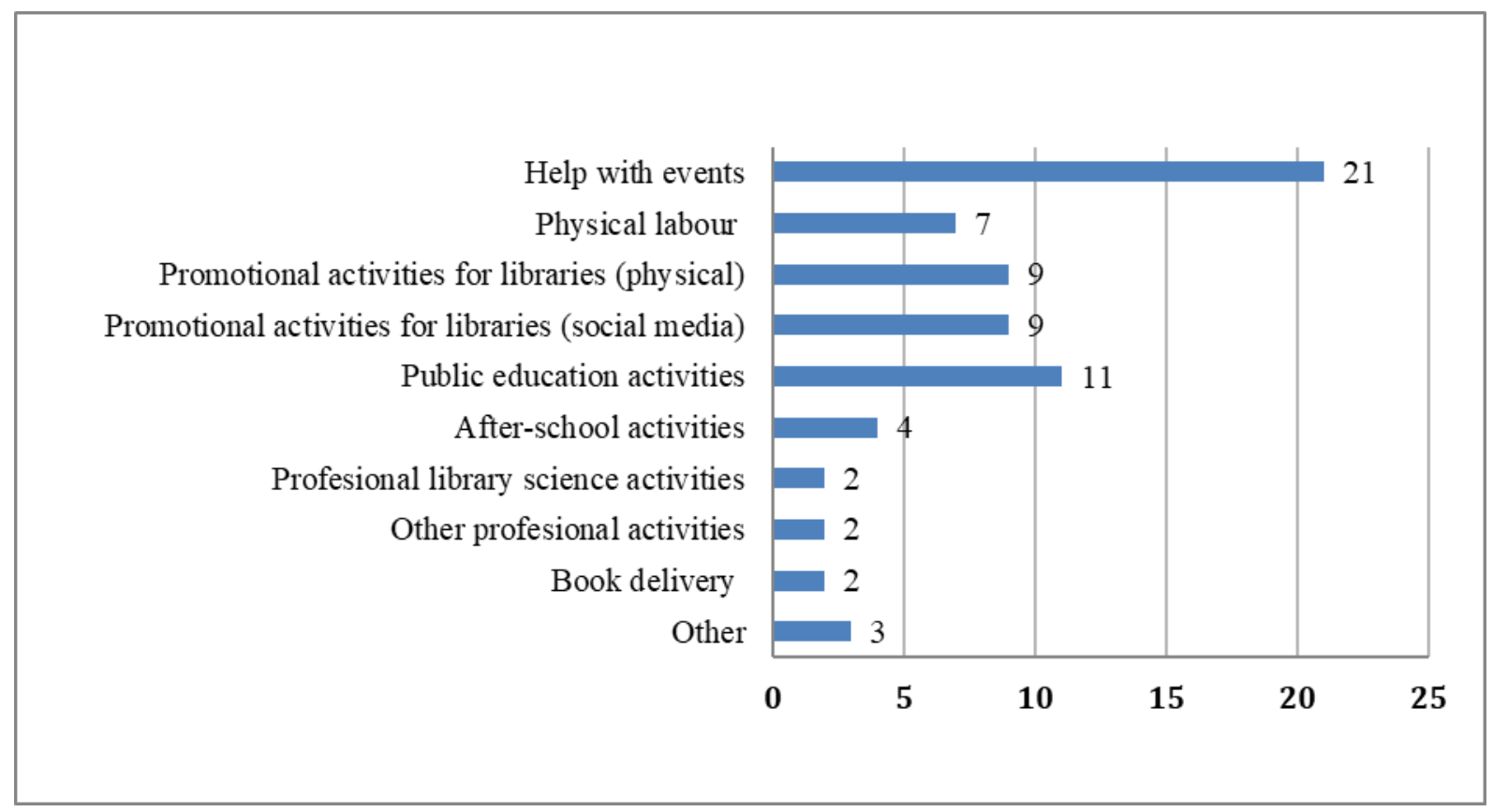

Fig. 8 Volunteers - activities 
Volunteers are mainly used in to help with events (21 cases), in public education activities (11) and in promoting the library. Book delivery services (2 cases), professional LIS activities (2 cases) and after school activities ( 4 cases) are the activities where volunteers are used the least.

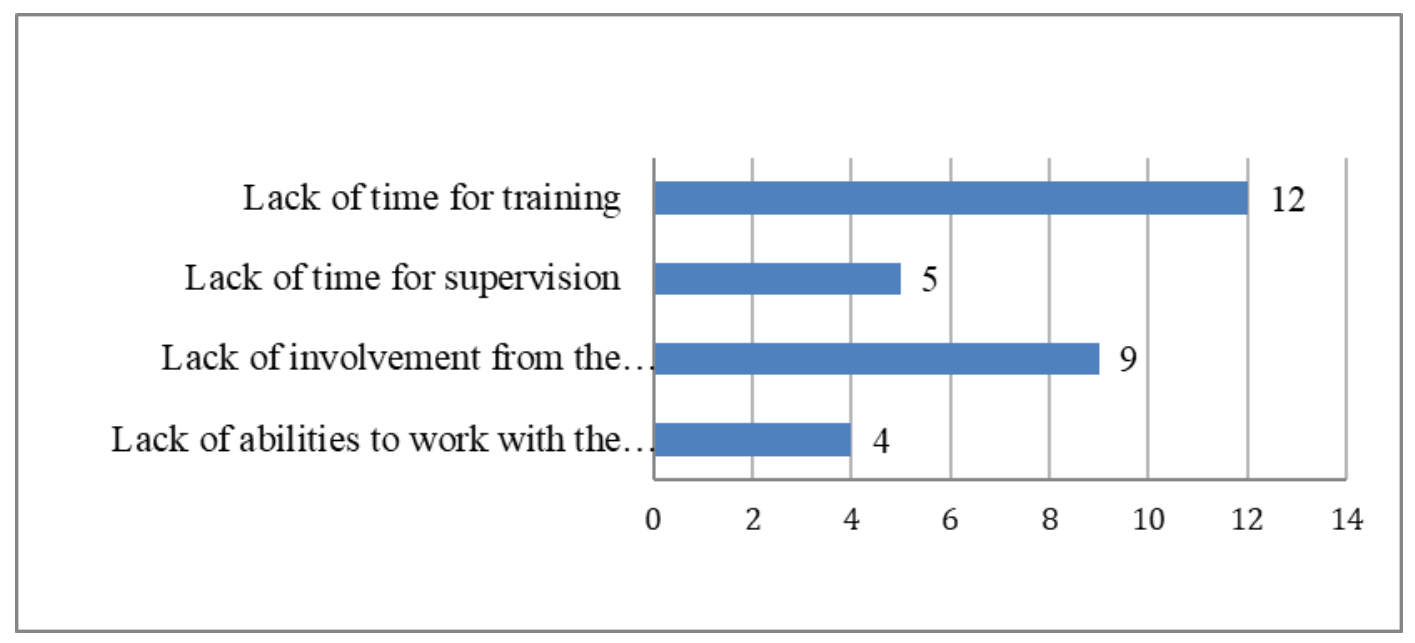

Fig. 9 Problems in working with volunteers

The main problems identified in working with volunteers are the lack of time for training volunteers and the low involvement from the volunteers. Lack of time for supervision and lack of abilities to work with the volunteers are not generally seen as problems.

\section{Conclusions}

The first conclusion of this study is the high number of libraries that did not answer the questionnaire (only 25 of the 43 libraries responded). This dramatically reduces the relevancy of this study but clearly shows us either a lack of interest in contributing to a library science study or a problem with internal institutional communication in the libraries that did not respond.

However, most of the analyzed libraries have volunteers (31 out of 43 - this includes data collected from the websites). This data is subject to upward change (because of the lack of responses) so we can consider this data as an encouraging starting point for the future of volunteering in Romanian libraries.

Most libraries do not provide information about volunteering on the site (22 out of 43). This includes some libraries that do use volunteers which makes us wonder how do they manage to get volunteers and if they would not profit from using the website to promote their volunteer programs.

We can identify a low involvement in organizing volunteering (the low number of libraries that offer training to volunteers, the fact that about half of the libraries do not have a volunteer management plan) with the existence of some situations in which volunteering is taken to another level (hundreds of volunteers, training etc.)

In general, there is a small number of volunteers (13 - median) per year that work in libraries. In our opinion, this should constitute a signal that more (and maybe not just more of the same but also different approaches) is needed to be done in order to attract volunteers in libraries.

Volunteers are mainly used in less intellectual activities (physical help in organizing events, other physical activities in the library etc.).

Lack of time has been identified as the main problem in working with volunteers and the second one is the low degree of involvement from the volunteers. Lack of skills to work with volunteers is not considered a problem (in only 4 out of the 24 libraries). 
Overall, the situation of the volunteers in the Romanian libraries is highly heterogenous, a fact that, we believe, reflects the overall status of these libraries. Some probably (and we use probably because of lack of data) do not use volunteers, the majority uses volunteers but only to a certain degree and without taking the volunteer activity to a higher level of organization, while a few libraries have developed well organized and successful volunteer programs, involving hundreds of volunteers each year.

This study was presented at the conference When the state sleeps, the citizens are involved! organized by the Transylvania Evangelical Academy in collaboration with Friedrich Naumann Foundation for Freedom Romania. 


\section{Interview with Delia Pantea, librarian in charge with methodological assistance, „Gheorghe Șincai" County Library Bihor}

We inaugurate through the material below the interview section of the Romanian Journal of Library and Information Science. This new section aims to bring opinions and comments directly from specialists in the field and other interested people. The first interview is with Mrs. Delia Pantea, librarian in charge with methodological assistance, "Gheorghe Sincai" County Library Bihor. The interview comes in the context in which the Bihor County Council decided to cut 17 occupied positions from the organizational chart of the county library and to abolish two branches.

The interview took place in December 2020 and was conducted by email.

Mihai Constantinescu: Can you briefly present the situation at the Bihor County Library?

Delia Pantea: Every change of administration creates waves in the first period after installation, now being in the health crisis period and in the near future in a possible economic crisis, the current situation was predictable since November when the president and vice president of Bihor County Council announced a new round of reductions in staff costs considering that they will bring major savings to the budget (https:/www.bihon.ro/stirile-judetului-bihor/reducerile-continua -in-era-bolojan-gal-anunta-economii-de- 12-million-euro-year-3581060/). This time, it was about cuts to institutions subordinated to the County Council (CC). The same article quotes the president of the CC: "They will work as badly as before, but with much reduced staff".

We expected this wave to come over the county library as well as over other subordinate institutions, we did not know when and how this major event will be managed. The wave came and left behind, at least at this time, an organization chart and an ROF (our note Regulation of Organization and Functioning) that seriously affects the functions of a county library.

Preservation function - permanently cut. The special collections, with heritage book, were left without the research position that the law allows.

The methodological function is currently subordinated to public relations.

Cataloging and acquisition are broken down and put into accounting as librarian positions.

The driver's job is abolished.

The activity of the whole library is reduced to a single shift.

M.C.: Were there discussions between authorities and librarians on budget cuts? If so, how did these discussions go?

D.P.: Of course, there were consultations, the president of the Bihor County Council was in the library and consulted with the manager and the administrative department. The Specialty department, the heads of services, were all informed of the need to operate reductions within the specialized personnel, but we were not asked in writing, neither verbally a service evaluation of the positions. We were asked for proposals for reductions without specifying criteria. It was said that there is a need to reduce the positions of "bosses" and then out of an impulse of altruism I said that I give up my position of boss (for health reasons) in the idea that the employees of the branches will be taken over by the public relations service with similar activity.

Revista Română de Biblioteconomie şi Ştiința Informării = Romanian Journal of Library and Information Science ISSN 2559-5490, ISSN-L 1841-1940 • Volume 16 Issue 22020 pp. 20-27 https://doi.org/10.26660/rrbsi.2020.16.2.20

This work is licensed under a Creative Commons Attribution-NonCommercial-NoDerivatives 4.0 International License 
The result was unexpected, they thought that with my reduction from office to close the branches and lay off almost all staff.

M.C.: What reasons did the authorities specify for these budget cuts?

D.P.: The library has entered the general wave of restructuring and budget cuts. We suspect that Pareto's law applies, a natural law, but which, apart from clear criteria of competence, will not bring anything good.

Certainly, the reduction of costs has been requested, but so far, we do not know why and how it led to such a drastic reduction of the activity of the branches, we do not know if other services have been subjected to the same calculation. We were waiting for a cost per service calculation to for all services, which is not available at this time.

M.C.: How will the population be affected by the closure of the two branches and by the shortening of the program at the rest of the branches and at the headquarters? What activities did these branches have?

D.P.: The branches already operated from 2019 on a single shift from 9 to 17 with two people. At that time we had complaints from users, but no one took them into account. Then there was the possibility to get until 19: 00 to the headquarters for school emergencies.

Now the branches and headquarters will all operate on a single shift from 10 to 18 .

The population that works from 9 or 10 to 17 or 18 will be directly affected.

For branches, the morning hours, which were not so crowded with readers, were planned for children's visits, for activities with the elderly. An employee took care of the guests, an employee took of the readers who requested books. A single person as expected to be the case, will not be able to do much.

Every year the branches had a component of their activity that addressed the neighborhood public, local schools, pensioners and in general the projects that we carried out in the network of the public libraries in Bihor we also carried out in branches aiming for the development of the community around the neighborhood library. There are too many to go into details but they are all visible on the blog of Bihor libraries: https://bibliotecibihorene.blogspot.com/search/label/filiale $\%$ 20ale\%20Bibliotecii\%20Jude\%C5\%A3ene

One of my goals in 2009 was for everyone to learn to post their activities, so everything that happened in the branches is and will be visible to anyone who wants to see.

M.C.: Do the persons living in Băile Felix still have access to a library?

D.P.: The library in Felix was the library where I grew up. The specter of a disappearance affects me personally. Tourists who came to the resort during the good touristic years, scheduled at least one visit to the library, among them, many writers came and left their recently published books.

For years, the Felix library was the only location in the resort that offered tourists and locals internet access, scanning and photocopying opportunities (we refer to the period between 2006 to 2014).

So, the answer is: the inhabitants of Felix, of the neighboring villages or tourists will no longer have access to books, internet services, scanning or photocopying.

M.C.: How will the library be affected by these changes? Do you think that readers will go to other branches or that the statistics will indicate a decrease in the use of the library? If you think that the usage of the library will suffer, isn't it possible that in a year's time we will see other budget cuts motivated by declining performance?

D.P.: Those who need books will look for solutions, they will look for other branches but many of those who lived nearby will probably give up. They will see the door closed and resign. 
In 2020, in the statistics downloaded on November 30, it was obvious that readers preferred to borrow books from branches more than from headquarters. I had calculated that the branches covered $48 \%$ of the book loan in a pandemic. The vast majority of the population will not realize the change of schedule. The consequence will be a decrease in terms of frequency and circulation indices. If the pandemic restrictions continue, the situation will worsen. As for the library services to community, it is difficult to predict how they will evolve. We can anticipate that there will be another reduction for reasons of inefficiency. These measures could continue to be applied until only the four doormen will remain to mow the grass around the empty building.

M.C.: What will happen to the documents hosted by the two libraries?

D.P.: If we refer to the library from Felix, there is a proposal to be taken over by the Sânmartin town hall. In this scenario, the library collections will be transferred to the school library of Sânmartin. Consequently, the access to the book will no longer be a public one but strictly limited to the pupils who attend that school. There is also a sadder scenario. This taking-over might be only formal, in the eyes of the press, and in the next 2-3 years the books would be melt. As for the other library, I don't know. I still hope the branch on Dacia Boulevard can be saved. If there had been a public consultation, the people of Oradea could have said: we need branches in the neighborhoods.

If an evaluation of all services had really been made, the branches would have remained and perhaps been developed. According to the principles of efficiency in serving the public, these things could have been possible by ensuring more staff at the branches and extending the opening hours.

M.C.: Is the library the only institution affected by these cuts?

D.P.: The same treatment is applied to all institutions subordinated to the County Council of Bihor, without mercy or negotiations, very quickly and with a minimum evaluation. The town halls of the administrative territorial units of Bihor will be in the same situation and, as a side effect, all the libraries that still operate in the county will be permanently closed.

Another local aberration is the legal disbandment of the Varad and Familia magazines as well as their absorption by the County Library. This transition of certain cultural brands to under a different one is a forced reorganization. The cultural brand (i.e. library) will be subject to new transformations or restrictions that will overshadow the brands of cultural magazines!?

M.C.: According to the data provided by the Institute of Statistics, annually, we are witnessing the closure of hundreds of libraries, the disappearance of branches and even the abolition of large libraries like the case of the Pedagogical Library (which was transformed into a section of Central University Library of Bucharest). How do you comment?

D.P.: Let's take a look at the history of each type of library. Hundreds of pages of bibliography tell us the story of each century's efforts to create libraries, their ephemeral life, the fragility of their position in the community.

This institution was founded by an intellectual elite who had the vision of an educated nation and imposed the institution. Later, the library was politically imposed and with party goals.

Unfortunately, at the end of the 20th century, the local administrations became responsible for the library and, no longer having the vision neither of the educated people nor party interests, they considered the libraries as parasitic or insignificant institutions. In the local monographies of Bihor (I browsed all those published in Bihor) only a few authors mention that they have or had a library in their village. So, I can even conclude that the library does not exist in the memory of the small community of Bihor. An in-depth analysis at each county level might lead to similar results. So, libraries can disappear from the map without anyone being upset. 
The one that should intervene, on the one hand, in the libraries' issues in the 21 st century is the beneficiary - to tell the administration - for the taxes I pay, I need the following quality services: education, culture, free access to books and information through libraries, roads, household water, electricity and so on.

On the other hand, a law that includes drastic sanctions for those who violate them, should protect the library as an institution, if the goal of an educated nation is still relevant.

And thirdly, we need a set of professional values of the profession that should encompass us all, from managers to the last employee of the communal library and no exception from these values should be accepted.

In the last ten years, the county libraries and international projects have tried to change the paradigm public library as a useless institution.

I did my best to develop and enhance the quality of the services of the libraries I worked for, whether libraries from Bihor or branches of the county library. Now, it's obvious that everything I've worked on is wiped with the sponge. At this moment, I really wish I am not right and that it this is just a lamentation caused by panic. 


\section{Interviu cu Delia Pantea, bibliotecar metodist, Biblioteca Județeană „Gheorghe Șincai” Bihor}

Inaugurăm prin materialul de mai jos secțiunea de interviuri a RRBSI. Această nouă secțiune își propune să aducă cititorilor opinii și comentarii direct de la specialiști ai domeniului și alte persoane interesate. Primul interviul este cu doamna Delia Pantea, bibliotecar metodist, Biblioteca Județeană „Gheorghe Șincai” Bihor. Interviul vine în contextul în care Consiliul Județean Bihor a decis tăierea a 17 posturi ocupate din organigrama bibliotecii județene și desființarea a două filiale.

Interviul a avut loc în decembrie 2020 și s-a desfășurat prin email.

Mihai Constantinescu: Puteți să ne prezentați, pe scurt, situația apărută la Biblioteca Județeană Bihor?

Delia Pantea: Fiecare schimbare de administraţie creează valuri in prima perioada de la instalare, acum fiind și în perioada de criză sanitară și în viitorul apropiat posibilă criză economică, situația actuală era previzibilă din noiembrie când președintele și vicepreședintele Consiliului Județean Bihor anunță o nouă rundă de reduceri de cheltuieli cu personalul considerând că acestea vor aduce economii majore, la buget (https://www.bihon.ro/stirile-judetului-bihor/reducerile-continuain-era-bolojan-gal-anunta-economii-de-12-milioane-de-euro-an-3581060/). De data aceasta, este vorba despre reduceri la instituții din subordinea Consiliului Județean. Același articol îl citează pe președintele CJ : "Vor lucra la fel de prost ca înainte, dar cu personalul mult diminuat".

Ne așteptam ca acest val să vină și peste biblioteca județeană ca și peste alte instituții subordonate, nu știam când și cum va fi gestionat acest eveniment major. Valul a venit și a lăsat în urmă, cel puțin la acest moment o organigramă și un ROF (n.n. Regulament de Organizare și Funcționare) care afectează grav funcțiile unei biblioteci județene.

Funcția de conservare - tăiată definitiv.

Colecțiile speciale, cu carte de patrimoniu, au rămas fără postul de cercetător pe care legea le permite.

Funcția metodică e la momentul de faţă în subordinea relațiilor cu publicul.

Catalogarea și achiziția sunt sparte și băgate ca posturi de bibliotecari în contabilitate.

Postul de șofer al județenei este desființat.

Se reduce activitatea întregii biblioteci pe un singur schimb.

M.C.: Au existat consultări între autorități și bibliotecari cu privire la tăierile de buget? Dacă da, cum au decurs aceste consultări?

D.P.: Desigur că au existat consultări, domnul președinte al CJ Bihor a fost in bibliotecă și s-a consultat cu managerul și departamentul administrativ. Departamentului de specialitate, șefilor de servicii, le-a fost adusă la cunoștință necesitatea de operare de reduceri în cadrul personalului de specialitate, dar nu ni s-a cerut în scris nici verbal, nici o evaluare pe servicii a posturilor. Ni s-au cerut propuneri de reduceri fără a se specifica criterii. S-a spus ca este nevoie de reducerea posturilor de "șefi" și atunci dintr-un impuls de altruism am spus că renunț la postul meu de șef (din motive de sănătate) în ideea că angajații fílialelor vor fi preluați de serviciul relații cu publicul, cu activitate similară.

Revista Română de Biblioteconomie şi Ştiința Informării = Romanian Journal of Library and Information Science ISSN 2559-5490, ISSN-L 1841-1940 • Volume 16 Issue 22020

This work is licensed under a Creative Commons Attribution-NonCommercial-NoDerivatives 4.0 International License 
Rezultatul a fost unul neașteptat, au gândit că odată cu reducerea mea din funcție să închidă și filialele și să disponibilizeze aproape tot personalul.

M.C.: Ce motive au precizat autoritățile pentru aceste tăieri de buget?

D.P.: Biblioteca a intrat în valul general al restructurărilor și reducerilor bugetare. Bănuim că se aplica acea lege a lui Pareto, lege naturală, dar care în afara unor criterii clare de competență nu va aduce nimic bun.

Cu siguranță s-a cerut reducerea de costuri, dar până în momentul de față nu știm de ce și cum s-a ajuns la reducerea atât de drastică a activității fílialelor, nu știm dacă alte servicii au fost supuse aceluiași calcul. Așteptam pentru toate serviciile să apară un calcul de cost/ serviciu, ceea ce până la ora actuala nu este disponibil.

M.C.: Cum va fi afectată populația de închiderea celor două filiale și de scurtarea programului la restul filialelor si la sediu? Ce activităţi aveau aceste filiale?

D.P.: Filialele deja din 2019 funcționau pe un singur schimb de la 9 la 17 cu două persoane. La acel moment am avut reclamații de la utilizatori, dar nimeni nu le-a băgat în seamă. Atunci mai exista posibilitatea de a ajunge până la 19 la sediu pentru urgențele școlare.

Acum și filialele și sediul vor funcționa toate pe un singur schimb de la 10 la 18.

Populaţia care lucrează de la 9 sau 10 până la 17 sau 18 va fi afectată direct.

Pentru filiale orele dimineții care nu erau atât de aglomerate cu cititori, erau planificate pentru vizite ale copiilor, pentru activităţi cu persoanele de vârsta a treia. Un angajat se ocupa de musafiri, un angajat se ocupa de cititorii care solicitau carte. Un om singur așa cum se preconizează nu va putea face mare lucru.

In fiecare an filialele aveau o componenta a activității care se adresa publicului de cartier, școlilor din proximitate, pensionarilor și în general proiectele pe care le-am derulat în rețea în bibliotecile publice din Bihor le-am derulat și în filiale urmărind dezvoltarea comunității în jurul bibliotecii de cartier. Sunt mult prea multe pentru a le detalia dar sunt toate vizibile pe blogul bibliotecilor bihorene:

https://bibliotecibihorene.blogspot.com/search/label/filiale\%20ale\%20Bibliotecii\%20Jude\%C5\% A3ene

Unul din obiectivele mele din 2009 a fost ca fiecare să învețe să-și posteze activitățile, deci tot ce s-a întâmplat în filiale este și va fi vizibil pentru cine dorește să vadă.

M.C.: Mai au persoanele din Băile Felix acces la bibliotecă?

D.P.: Biblioteca din Felix a fost biblioteca unde am crescut eu. Spectrul unei dispariții mă afectează personal. Turiștii care veneau în stațiune, în anii turistici buni, își programau măcar o vizită la bibliotecă, printre ei, mulți scriitori veneau pentru a lăsa cărțile lor recent apărute. Ani de zile biblioteca din Felix a fost singura locație din stațiune care oferea turiștilor și localnicilor acces la internet, posibilități de scanare și copiere xerox (ne referim la 2006 până în 2014). Deci răspunsul este: locuitorii Felixului, ai satelor învecinate sau turiști nu vor mai avea nici acces la carte, nici la servicii de internet, scanare sau xerox.

M.C.: Cum va fi afectată bibliotecă de aceste schimbări? Credeți că cititorii se vor duce la alte filiale sau că statistica va indica o scădere a utilizării bibliotecii? Dacă considerați că utilizarea bibliotecii va avea de suferit, nu cumva e posibil ca peste un an să asistăm la alte tăieri de buget motivate de performanțe în scădere?

D.P.: Cei care au nevoie de cărți vor căuta soluții, vor căuta alte filiale dar mulți dintre cei care locuiau în apropiere probabil vor renunța. Vor vedea ușa închisă și se vor resemna.

În anul 2020, în statistica descărcată la 30 noiembrie era evident că cititorii au preferat să împrumute carte de la filiale în mai mare măsură decât de la sediu. Făcusem un calcul că filialele au acoperit în pandemie 48 \% din împrumutul de carte. 
Populația, în marea ei majoritate, nu își va da seama de schimbarea de program. Consecința va fi scăderea indicilor de frecvență și circulație. Dacă restricțiile de pandemie continuă situaţia se va agrava. Despre evenimentele, activitățile cu publicul situația e greu previzibilă. Şi atunci pe motive de ineficiență se va mai opera o reducere. Apoi încă una până vor rămâne doar cei 4 portari care sa tundă iarba în jurul clădirii goale.

M.C.: Ce se va întâmpla cu documentele găzduite de cele două biblioteci?

D.P.: Pentru biblioteca din Felix, se propune o preluare de către primăria Sânmartin care o va da către biblioteca școlară deci accesul la carte nu va mai fi unul public ci unul limitat strict la elevii școlii respective. Mai există și un scenariu mai trist. Preluarea să fie doar formală, de ochii presei, iar în 2-3 ani cartea să ajungă la topit. Pentru cealaltă nu știu. Eu sper încă să salvăm Filiala de pe Bulevardul Dacia. Dacă s-ar fi făcut consultare publică, orădeni ar fi putut spune: avem nevoie de filiale în cartiere. Dacă s-ar fi făcut cu adevărat o evaluare a tuturor serviciilor, filialele ar fi rămas și ar fi fost poate dezvoltate, asigurând în cartiere personal mai mult, program mai lung conform unor principii de eficiență în servirea publicului.

M.C.: Este biblioteca singura instituție afectată de aceste tăieri?

D.P.: Toate instituțiile subordonate la CJ Bihor sunt supuse aceluiași tratament, fără milă, fără negocieri, foarte repede, cu o evaluare minimă. Vor urma primăriile din unităţile administrativteritoriale bihorene și ca efect secundar vor fi închise definitiv toate bibliotecile care mai funcționează în Bihor.

O altă aberație locală e desființarea juridică a revistelor Varad și Familia și absorbția lor de către Biblioteca Județeană. Este o reorganizare forțată această trecere a unor mărci culturale sub o altă marcă culturală cu alt specific. Marca culturală (biblioteca) va fi supusă unor noi transformări sau restricții care vor duce mai tare în umbră mărcile revistelor culturale!?!

M.C.: Asistăm anual la închiderea a sute de biblioteci (conform datelor de la Institutul de Statistică), la dispariția unor filiale și chiar la desființarea unor biblioteci mari - cum a fost cazul Bibliotecii Pedagogice (transformată în secție a BCU București). Cum comentați această situație?

D.P.: Să aruncăm o privire în istoria fiecărui tip de bibliotecă. Sute de pagini de bibliografie povestesc eforturile fiecărui secol de a crea biblioteci, viața lor efemeră, fragilitatea poziției în comunitate. Populației de pe teritoriul actual al României i-a fost impusă această instituţie de o elită intelectuală care avea viziunea unui popor educat. Mai târziu instituţia a fost impusă politic cu obiective de partid. Din păcate, la sfârșitul secolului XX administrațiile locale, în grija cărora a ajuns biblioteca, nemaiavând nici viziunea poporului educat nici interese de partid, au considerat bibliotecile instituții parazite sau nesemnificative. În monografiile locale bihorene (le-am răsfoit pe toate care au apărut în Bihor) doar puțini autori amintesc că au, sau au avut o bibliotecă în sat, deci chiar pot generaliza, în memoria comunității mici bihorene biblioteca nu există.

Un studiu mai amplu la nivelul fiecărui județ ar avea poate rezultate similare. Deci bibliotecile pot dispărea de pe hartă fără ca măcar cineva să fie deranjat.

Cel care ar trebui să intervină pe de-o parte în problematica bibliotecilor în secolul XXI este beneficiarul - să spună - tu ordonator de credite, pentru impozitele mele am nevoie de următoarele servicii de calitate - educație, cultură, acces gratuit la carte și informație prin biblioteci, șosele, apă curentă, electricitate...

Pe de altă parte, o lege cu sancțiuni drastice pentru cei care le încalcă, ar trebui să protejeze biblioteca ca instituție, dacă obiectivul popor educat mai e de actualitate.

Iar în al treilea rând, avem nevoie de un set de valori ale profesiei de la care să nu se facă rabat ... care să ne înglobeze pe toți de la manageri până la ultimul angajat de bibliotecă comunală.

Bibliotecile județene și proiectele internaționale au încercat în ultimii 10 ani să schimbe paradigma biblioteca publică - instituție inutilă. 
Eu am dorit și am încercat să fac parte din dezvoltarea și creșterea calității serviciilor bibliotecilor cu care am lucrat, biblioteci din Bihor sau filiale ale județenei. Acum e evident că tot ce am muncit este șters cu buretele. În acest moment chiar îmi doresc să nu am dreptate și să fie doar o lamentație determinată de panică. 